\title{
Melting and metasomatism/refertilisation processes in the Patagonian sub- continental lithospheric mantle: A review
}

Article in Lithos · December 2019

DOI: 10.1016/j.lithos.2019.105324

CITATIONS

0

6 authors, including:

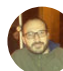

Massimiliano Melchiorre

Spanish National Research Council

42 PUBLICATIONS 90 CITATIONS

SEE PROFILE

Michel Grégoire

French National Centre for Scientific Research

220 PUBLICATIONS 3,123 CITATIONS

SEE PROFILE
READS

22

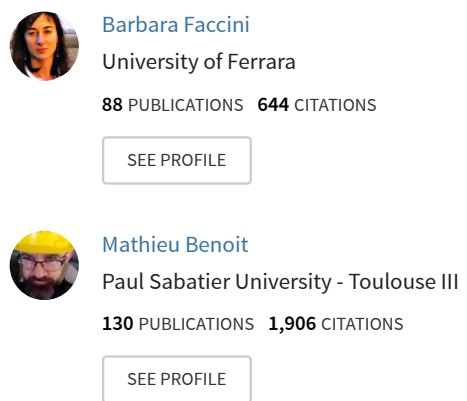

Some of the authors of this publication are also working on these related projects:

Origin and evolution of ultra-refractory peridotites in oceanic large igneous provinces View project

Geochemistry of noble gases and $\mathrm{CO} 2$ in mantle xenoliths from Europe and circum-Mediterranean area View project 


\section{Journal Pre-proof}

Melting and metasomatism/refertilisation processes in the Patagonian sub-continental lithospheric mantle: A review

Massimiliano Melchiorre, Barbara Faccini, Michel Gregoire, Mathieu Benoit, Federico Casetta, Massimo Coltorti

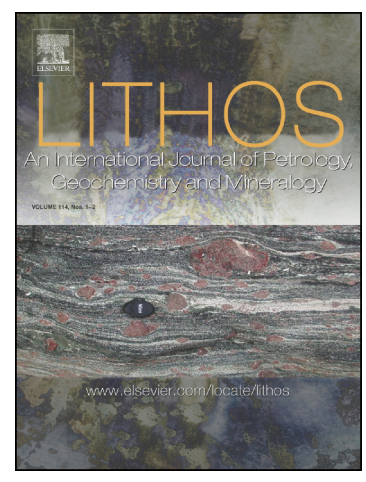

PII: $\quad$ S0024-4937(19)30484-0

DOI: $\quad$ https://doi.org/10.1016/j.lithos.2019.105324

Reference: $\quad$ LITHOS 105324

To appear in: $\quad$ LITHOS

Received date: $\quad 10$ April 2019

Revised date: $\quad 26$ November 2019

Accepted date: $\quad 4$ December 2019

Please cite this article as: M. Melchiorre, B. Faccini, M. Gregoire, et al., Melting and metasomatism/refertilisation processes in the Patagonian sub-continental lithospheric mantle: A review, LITHOS(2019), https://doi.org/10.1016/j.lithos.2019.105324

This is a PDF file of an article that has undergone enhancements after acceptance, such as the addition of a cover page and metadata, and formatting for readability, but it is not yet the definitive version of record. This version will undergo additional copyediting, typesetting and review before it is published in its final form, but we are providing this version to give early visibility of the article. Please note that, during the production process, errors may be discovered which could affect the content, and all legal disclaimers that apply to the journal pertain.

(C) 2019 Published by Elsevier. 


\section{Melting and metasomatism/refertilisation processes in the Patagonian}

\section{Sub-Continental Lithospheric Mantle: a review}

Massimiliano Melchiorre ${ }^{a, b}$, Barbara Faccinib ${ }^{*}$, Michel Gregoire ${ }^{c}$, Mathieu Benoit ${ }^{c}$, Federico Casetta $^{b}$, Massimo Coltorti ${ }^{b}$

a Institute of Earth Sciences Jaume Almera, CSIC, Carrer Luís Sor: i Sabarís s/n, 08028 Barcelona, Spain.

${ }^{\mathrm{b}}$ Department of Physics and Earth Sciences, University of Ferrara, Via Saragat 1, 44121 Ferrara, Italy.

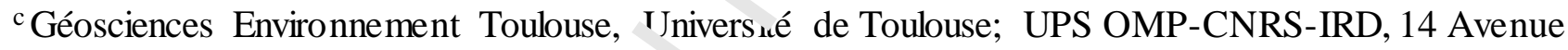
E. Belin, 31400 Toulouse, France.

*Corresponding author: Barbara F...cini, Department of Physics and Earth Sciences, University of Ferrara, Via Saragat 1, $41^{1} 1^{\prime}<1$ Ff rrara, Italy. E-mail address: barbara.faccini@ unife.it 


\section{Melting and metasomatism/refertilisation processes in the Patagonian Sub-Continental}

\section{Lithospheric Mantle: a review}

\section{Abstract}

The large amount of geochemical variability in peridotitic and pyroxenitic xenoliths exhumed by Eocene to present-day magmas in Patagonia provides a unique opportunity to investigate the depletion and enrichment processes affecting the lithosphere in proximity of subduction settings and their relationships with magmatism. In this study, a review of the geochemical features of the Patagonian ultramafic xenoliths coupled with new $\mathrm{Sr}-\mathrm{Nd}$ isotopir $\mathrm{d}_{a}{ }^{\top} ?$ on clinopyroxene separates from representative suites enabled us to delineate the $\mathrm{r}$ all melt extraction and enrichment (metasomatism vs. refertilisation) processes acting in thes sub-continental lithospheric mantle (SCLM) portions. Our findings show that clinopyro e. $^{2}$ s and orthopyroxenes in Patagonian harzburgites/lherzolites lie on two discrete $\mathrm{Al}_{2} \mathrm{C}_{3}$ i , ot trends and record variable partial melting degrees (1-30\%), progressively decreasing $\mathrm{ol}^{\prime} \mathrm{n}$ ward, where the mantle domains experienced melt extraction in the past. The occurrence of $\iota$ th negative and positive correlations between $(\mathrm{La} / \mathrm{Yb})_{\mathrm{N}}$, $\mathrm{Sr}_{\mathrm{N}}$, and $\mathrm{Al}_{2} \mathrm{O}_{3}$ in clinopyroxenes $\operatorname{siog} \mathrm{cot}_{\mathrm{c}}$, that large part of the SCLM beneath Patagonia was affected by both metasomatic (low nelt-fluid/rock ratio) and refertilisation (high melt-fluid/rock ratio or long-lasting low melt-fluid// nk interaction) processes, while a few portions - particularly in Southern Patagonia - were Jevuld of significant enrichment processes. A comprehensive study of the major/trace element composition and rare earth element patterns of clinopyroxene from both cumulitic and mantle xenoliths led us to hypothesize that tholeiitic enrichment was followed by infiltration of transitional/alkaline agents in the Northern and Central Patagonian SCLM. The percolation of melts with transitional affinity can be identified in some Central Patagonian localities. In Southern Patagonia clinopyroxenes record a slight interaction with alkaline and proto-adakitic agents; the latter occurred at Cerro Fraile, the locality nearest the trench. The $\mathrm{Sr}-\mathrm{Nd}$ xenolith isotopic signature led to speculation that enriched and depleted mantle components interacted variably in the SCLM domain beneath Patagonia. This work suggests that a detailed and comprehensive study of 
ultramafic xenoliths can help identify the evidence produced by magmatic events occurring at the surface, as both a serial affinity and a temporal sequence.

Keywords: Patagonia, Sub-Continental Lithospheric Mantle, alkaline metasomatism, tholeiitic refertilisation

\section{Introduction}

The mantle xenoliths brought to the surface in the proximity of cubcistion settings are a powerful tool to investigate the depletion and enrichment processes all tong the lithospheric mantle. The dehydration of the subducting slab can lower the melting $n_{\iota}$ int of the overlying mantle wedge and trigger melt extraction (depletion processes). Enrichment $\mathrm{p}_{\mathbf{\imath}}$ cesses are instead ascribed to the release of fluids/melts that modify the chemical composition. of the mantle by adding incompatible elements (in some cases changing the major eleme - $^{-}$udget as well) and eventually affecting its isotopic composition. Once transported to the sunce, mantle xenoliths can signal these depletion and/or enrichment processes; the former are rela or. to partial melting and the latter to both metasomatic and refertilisation events. Patagonia is a key locality for investigating depletion/enrichment processes affecting the mantle wedge in $l$ s, roximity of a subducting slab. Throughout the entire Patagonian region, from the Eocene w tue present, plateau magmatism with tholeiitic to transitional/alkaline affinity transported large amounts of peridotitic and pyroxenitic xenoliths from the underlying lithosphere to the surface (Fig. 1). The large geochemical variability of these xenoliths provides evidence for moderate to strong depletion events (up to $30 \%$ partial melting) affecting the subcontinental lithospheric mantle (SCLM) wedge beneath Patagonia and for subsequent variable metasomatic/refertilisation processes (Aliani et al., 2009; Bjerg et al., 2005, 2009; Conceicao et al., 2005; Dantas, 2007; Dantas et al., 2009; Faccini et al., 2013; Gorring and Kay, 2000; Kilian and Stern, 2002; Laurora et al., 2001; Melchiorre et al., 2015; Mundl et al., 2015, 2016; Ntaflos et al., 2007; Rivalenti et al., 2004, 2007; Schilling et al, 2005, 2008, 2017; Stern et al., 1999). Nevertheless, 
the nature and provenance of fluids/melts pervading this mantle wedge is still debated, while a comprehensive model of the depletion and enrichment processes affecting the Patagonian SCLM is still far from settled.

In some localities, the interaction between slab-derived fluids and previously depleted mantle domains is evidenced by the presence of modal amphibole and phlogopite (Comallo and Gobernador Gregores, n. 6 and 20 in Fig. 1, respectively; Laurora et al., 2001; Mundl et al., 2016). The occurrence of slab-derived melts has been proposed at Cerro Fraile (n. 23 in Fig. 1) by Kilian and Stern (2002), who related the high $\mathrm{Sr} / \mathrm{Y}, \mathrm{La} / \mathrm{Yb}$, and $\mathrm{La} / \mathrm{Nb}$ ratios of the mantle xenc. iths to the infiltration of highMg\#, low-Y adakitic melts similar in composition to those in he neighbouring Austral Volcanic Zone. Further support for this hypothesis was provided hv Gaccini et al. (2013) who ascribed the enrichment in $\mathrm{Zr}$, Th, and $\mathrm{U}$ of pyroxenes from Cerro $\mathrm{F}_{1}$. 'le xenoliths to the slab melting of $\mathrm{Mn}$ nodules and organic-rich sediments present on the c ea 1 floor of the Antarctic Plate.

In some localities (Prahuaniyeu, n. 8 in Fig. 1) ne low Ti/Nb and high $\mathrm{Zr} / \mathrm{Hf}$ ratios of spinel-bearing peridotites promote the percolation of carb natitic melts through the Patagonian lithosphere (Bjerg et al., 2009). The occurrence of carbontitic retasomatism was also invoked for some xenoliths from Estancia Lote 17 (Gobernador Grc rores, n. 20 in Fig. 1; Gorring and Kay, 2000), even though Aliani et al. (2009) recently dismissed a r.antle origin for such occurrence, suggesting that at least part of the carbonate was introducet is the xenoliths by percolating meteoric water.

Negative correlations between $(\mathrm{La} / \mathrm{Yb})_{\mathrm{N}}$ and $\mathrm{Al}_{2} \mathrm{O}_{3}$ and between $\mathrm{Sr}_{\mathrm{N}}$ and $\mathrm{Al}_{2} \mathrm{O}_{3}$ in clinopyroxe nes, together with the presence of orthopyroxenitic veins, led Melchiorre et al. (2015) to hypothesize that a refertilisation event triggered by transitional alkaline/sub-alkaline melts occurred in the SCLM beneath Estancia Sol de Mayo (n. 16 in Fig. 1).

In some localities mantle xenoliths devoid of any significant metasomatic imprint were also documented, as in the case of Tres Lagos (n. 22 in Fig. 1), where a suite of nodules record only partial melting events in the garnet and spinel stability fields (Ntaflos et al., 2007). 
Mundl et al. (2015, 2016) and Schilling et al. (2017) proposed the existence of multiple discrete SCLM domains with different depletion ages beneath Patagonia based on Re-Os systematics. According to these authors, the mantle domain beneath Pali Aike (n. 25 in Fig. 1) yields the oldest depletion ages (up to $2.5 \mathrm{Ga}$ ), whereas the SCLM beneath the northern localities are characterized by younger ages varying between 0.5 and $1.0 \mathrm{Ga}$.

In the present study, a review of the main geochemical features of several Patagonia mantle xenolith suites, strengthened by new $\mathrm{Sr}-\mathrm{Nd}$ isotopic analyses of clinopyroxene separates from representative localities, is advanced. Main goals are to: i) investigate (and disrrimi ' rate between) metasomat is $\mathrm{m}$ and refertilisation processes affecting the mantle domains; ii c nstrain the nature of the melt/fluid circulating in the Patagonian SCLM; iii) evaluate the pocsu'a interactions among different mantle reservoirs and iv) identify the presence (if any) of large-sca ${ }^{\circ}$ depletion/enrichment processes in the SCLM beneath Patagonia.

A further consideration concerns the type of nemical modification of the mantle, namely, if the enrichment process is related to a metasoma ${ }^{+}$ic (either cryptic or modal) or a refertilisation event. The term metasomatism defines the sub-snlid is modification of a rock's chemical composition, through invasive percolation of/reaction $\mathrm{w}: \mathrm{h}$ liquids. If the original solid-solution phase assemblage remains the same but changes in comno itir n, metasomatism is defined as "cryptic", whereas if new phases are added to the pristine mis 'ra paragenesis, the metasomatism is defined as "modal" (O'Reilly and Griffin, 2013). On the other hand, a refertilisation event is identified when a previously depleted peridotitic rock is impregnated by percolating melts that are able to impart a new and usually more fertile mineralogical and chemical composition (Le Roux et al., 2007; Pelorosso et al., 2016). This case can be identified with the concept of "stealth" metasomatism introduced by O'Reilly and Griffin (2013), who highlighted the difficulty in identifying the eventual enrichment process when it ends with a mineralogical/chemical composition comparable to that of the starting fertile mantle. 
Under the assumption that the processes of metasomatism and refertilisation are essentially related to different melt/rock ratios, in this work we speculate about the different effects that these processes may have had on the peridotitic matrix in various localities throughout Patagonia.

\section{Geological setting}

Patagonia is the continental region of South America lying south of the Huincul Fault (Ramos et al., 2004; Schilling et al., 2017). It extends from $\sim 39^{\circ}$ and $\sim 54^{\circ} \mathrm{S}$ between the Southern and Austral Volcanic Zones (the SVZ and AVZ, respectively), the two southen. nost portions of the Andean Cordillera (Stern and Kilian, 1996). The subduction of the Crile kidge beneath the South American Plate, occurring in conjunction with the so-called Triple Junc ion (46.3 S; Cande and Leslie, 1986), marks the separation between SVZ and AVZ and is refluck 'd by a gap in the volcanism from 46 to $49^{\circ}$ S (D’Orazio et al., 2000; Fig. 1).

Patagonia consists of three geographical i "ovinces (Rio Negro, Chubut, and Santa Cruz) and is characterized by the presence of several Incene to Holocene volcanic plateaus located behind the Andean arc chain (Fig. 1; see Kay et n1., 'n J4; Ramos and Kay, 1992). These plateaus, composed of transitional to alkaline lavas, genc: ally developed in three evolutionary stages: "pre-plateau", "main plateau", and "post-plateau", the se zond being the most voluminous. The Somoncura Volcanic Field (Fig. 1) is considered the la. rest post-Eocene mafic volcanic field within Patagonia (Kay et al., 2007). It consists of a series of Oligocene to early Miocene volcanic fields covering more than 55,000 $\mathrm{km}^{2}$ in the Meseta de Somoncura and surrounding regions (Meseta de Cari Laufquen and Meseta de Canquel). It overlies Cretaceous to early Tertiary volcanic and sedimentary rocks (Ardolino et al., 1999; Rapela and Kay, 1988; Rapela et al., 1988), the extensive Jurassic silicic volcanic rocks of the Chon Aike Province (Kay et al., 1989; Pankhurst and Rapela, 1995), and a late Precambrian to Palaeozoic magmatic and metamorphic basement. The unique geodynamic setting of the volcanic gap region, related to the Middle Eocene to present northward migration of the Chile Triple Junction (from $\sim 49^{\circ} \mathrm{S}$ to $46.3^{\circ} \mathrm{S}$; Cande and Leslie, 1986), resulted in extensive Late Miocene to Pleistocene 
magma production. The volcanic activity of the southern portions of Patagonia consists of a voluminous, tholeiitic to transitional Late Miocene to Early Pliocene main plateau sequence (Meseta de la Muerte, Belgrano, Central, and Lago Buenos Aires) and of a less voluminous, transitional to alkaline late Miocene to Plio-Pleistocene post-plateau sequence (Gorring et al., 1997). The youngest (Pliocene to present) Patagonian lava flows constitute the Pali Aike Volcanic Field $\left(49-52^{\circ}\right.$ S; Stern et al, 1989), a 4,500- $\mathrm{km}^{2}$ succession of alkaline basaltic lava flows and subordinated monogenetic structures such as maars, tuff-rings, scoria, and spatter cones (D'Orazio et al., 2000). These small volcanic centres are aligned ENE-WSW and NW-SE, and are nrou bly linked to the still-active Magallanes Strait Rift System (Diraison et al., 1997) and to un Mesozoic Patagonian Austral Rift (Corbella et al., 1996), respectively.

Most of the Eocene to present plateau lavas brought ccnss arable quantities of mantle xenoliths to the surface, mainly peridotitic in composition, vit. le,s abundant pyroxenites. A summary of the known Patagonian xenolith-bearing localiti - i, reported in Fig. 1 (see Aliani et al., 2009; Bjerg et al., 2005, 2009; Conceicao et al., 2005; Daı`'`s, 2007; Dantas et al., 2009; Faccini et al., 2013; Gorring and Kay, 2000; Kilian and Stern, 20n7; s urora et al., 2001; Melchiorre et al., 2015; Mundl et al., 2015, 2016; Ntaflos et al., 2007; F valeıti et al., 2004, 2007; Schilling et al., 2005, 2008, 2017; Stern et al., 1999).

According to Bjerg et al. (20)y), Dantas (2007), Dantas et al. (2009), Folguera et al. (2018), Kay et al. (2013), Melchiorre et al. (2015), and Rivalenti et al. (2004), Patagonia can be subdivided into three

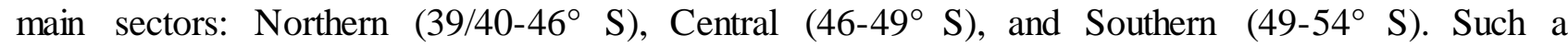
subdivision is particularly effective to emphasize the features of the Central Patagonian mantle region, which experienced Middle Eocene to present interactions with the subducting Chile Ridge (Cande and Leslie, 1986; Folguera et al., 2018). Further support to this discrimination is given by the (few) ages reported for the xenolith-bearing volcanic products (basaltic necks, cinder cones, scoria cones, and maars) in the literature; these are generally younger moving southwards. The xenolith-bearing volcanic products located north of the Chile Triple Junction were, in fact, emplaced after $61 \mathrm{Ma}$; 
those from Central and Southern Patagonia are younger than 42 and $7 \mathrm{Ma}$, respectively (see Bjerg et al., 2005; Dantas, 2007; Dantas et al., 2009; Melchiorre et al., 2015; Mundl et al., 2015; 2016; Schilling et al., 2017). In this framework, we consider the following localities as belonging to Northern Patagonia (Fig. 1): Laguna Fria (1), Cerro Chenque (2), Puesto Diaz (3), Estancia Alvarez (4), Cerro Aznares (5), Comallo (6), Cerro Mojon (7), Prahuaniyeu (8), Traful (9), Cerro Rio Chubut (10), Paso de los Indios (11), Cerro de los Chenques (12), and Coyhaique (13). Central Patagonia is represented by Chile Chico (14), Cerro Clark (15), Estancia Sol de Mayo (16), Don Camilo (17), Cerro Cuadrado (18), Auvernia (19), Gobernador Gregores + Fsta. -ia Lote 17 (20), and Cerro Redondo (21). Southern Patagonia includes Tres Lagos (22) c.rro Fraile (23), Las Cumbres (24), and Pali Aike (25).

\section{Sample localities and analytical methods}

${ }^{87} \mathrm{Sr} /{ }^{86} \mathrm{Sr}$ and ${ }^{143} \mathrm{Nd} /{ }^{144} / \mathrm{Nd}$ isotopic measure, ner.s were performed on clinopyroxene separates from 29 samples from 7 Patagonian localities, thought to be representative of the SCLM beneath the Northern, Central, and Southern regins $\cdots$ nprising Cerro Rio Chubut (n. 10 in Fig. 1), Cerro de los Chenques (n. 12 in Fig. 1), Cerrc Claı kn (n. 15 in Fig. 1), Estancia Sol de Mayo (n. 16 in Fig. 1), Gobernador Gregores (n. 20 in Fio 1), Cerro Fraile (n. 23 in Fig. 1), and Pali Aike (n. 25 in Fig. 1). A summary of the petrogin nh features of the analysed samples is given in Appendix A, whereas major/trace element analyses of selected clinopyroxenes from the above localities (Table 1) are reported by Aliani et al. (2009), Dantas (2007), Dantas et al. (2009), Faccini et al. (2013), and Melchiorre et al. (2015). ${ }^{87} \mathrm{Sr} /{ }^{86} \mathrm{Sr}$ and ${ }^{143} \mathrm{Nd} /{ }^{144} \mathrm{Nd}$ were measured with a thermal ionization mass spectrometer (TIMS) at the UMR 5563 (GET, Observatoire Midi-Pyrenees) of the University Paul Sabatiér (Toulouse III). Measurements of $\mathrm{Sr}$ and $\mathrm{Nd}$ isotopic ratios were realized on leached handpicked clinopyroxenes, following the method described in Snow et al. (1994) and used in Benoit et al. (1999), to reduce the effect of the hydrothermal fluid-rock interactions, which mainly affect the ${ }^{87} \mathrm{Sr} /{ }^{86} \mathrm{Sr}$ ratios. Leached clinopyroxenes underwent acid digestion with a mixture of $\mathrm{HF}-\mathrm{HClO}_{4}$ at 
$140^{\circ} \mathrm{C}$, to prevent the formation of Cafluorides, which trap rare earth elements (REE). Sample drying was done at the same temperature until the complete evaporation of $\mathrm{HClO}_{4}$. Chemical separation was performed on combined Sr-Spec/Thru-Spec columns. The Sr cut was processed again through the same column to efficiently separate $\mathrm{Sr}$ from $\mathrm{Rb}$ and $\mathrm{Ca}$, while $\mathrm{Nd}$ was further eluted on $\mathrm{LnSpec}$ Eichrom resin. Isotopic measurements were conducted on a Finnigan Mat 261 mass spectrometer. Sr was run on a single $\mathrm{W}$ filament with $\mathrm{Ta}$ activator, while $\mathrm{Nd}$ was run on a Re double filament. The NBS 987 (for Sr) and La Jolla (for Nd) standards were run regularly to check the measurements: the average value of ${ }^{87} \mathrm{Sr} /{ }^{86} \mathrm{Sr}=0.710248 \pm 0.000020(\mathrm{n}=17)$, average value ${ }^{87} \mathrm{Sr} /{ }^{86} \mathrm{Sr}=0.710246 \pm$ $0.000012(\mathrm{n}=23)$, and average value ${ }^{143} \mathrm{Nd} /{ }^{144} \mathrm{Nd}=0.51185 j-0.000010(\mathrm{n}=16)$. Blanks were < $650 \mathrm{pg}$ for $\mathrm{Sr}$ and $<350 \mathrm{pg}$ for $\mathrm{Nd}$.

\section{Clinopyroxene, orthopyroxene and olivine c'se. is ry}

\subsection{Summary of previously published dat.}

Clinopyroxenes from Northern, Central an' ${ }^{\prime}$ Southern Patagonia mantle xenoliths depict steep trends characterized by a $\mathrm{Mg \#}$ [calculated ar $\mathrm{M}_{\llcorner}{ }^{\prime}\left(\mathrm{Mg}+\mathrm{Fe}^{2+}\right) \mathrm{mol} \%$, by considering all $\mathrm{Fe}$ as $\mathrm{Fe}^{2+}$ ] increase coupled with an $\mathrm{Al}_{2} \mathrm{O}_{3}$ content deciease (Fig. 2). Clinopyroxenes from Northern Patagonia harzburgites and lherzolites hav $\mathrm{N}$ ig\# varying between 88.3 and 95.0, with $\mathrm{Al}_{2} \mathrm{O}_{3}$ ranging from 8.0 to 1.7 wt.\%, showing a s ou linear correlation (Fig. 2a). The distribution of $\mathrm{Al}_{2} \mathrm{O}_{3}$ vs. $\mathrm{Mg \#}$ in clinopyroxenes from Central Patagonian harzburgites and lherzolites is scattered, notwithstanding similar compositional ranges (Mg\# 87.9-94.4; $\mathrm{Al}_{2} \mathrm{O}_{3}$ 1.8-7.1 wt.\%; Fig. 2b). The case of clinopyroxenes in Southern Patagonia harzburgites and lherzolites (Fig. 2c) is slightly different, exhibiting substantially lower $\mathrm{Al}_{2} \mathrm{O}_{3}$ content (0.6-6.8 wt.\%) at comparable $\mathrm{Mg \#} \mathrm{(88.4-94.1).}$

Clinopyroxenes from Northern Patagonia dunites and websterites (Fig. 2d) plot on two discrete trends, one of which is comparable to that of harzburgites and lherzolites ( $\mathrm{Mg} \#$ 89.1-92.7; $\mathrm{Al}_{2} \mathrm{O}_{3}$ 3.87.5 wt.\%) whereas the other is typified by a lower $\mathrm{Al}_{2} \mathrm{O}_{3} / \mathrm{Mg} \#$ ratio ( $\mathrm{Mg \#} \mathrm{83.9-89.8;} \mathrm{Al}_{2} \mathrm{O}_{3}$ 2.6-5.2 wt.\%). Clinopyroxenes in Central Patagonian dunites, wehrlites, websterites, and clinopyroxenites 
(Fig. 2e) have similar features, as demonstrated by the presence of two trends with high and low $\mathrm{Al}_{2} \mathrm{O}_{3} / \mathrm{Mg} \#$ ratios $\left(\mathrm{Mg} \#\right.$ 89.5-92.9 and $\mathrm{Al}_{2} \mathrm{O}_{3}$ 4.0-7.2 wt.\% the former; $\mathrm{Mg \#} \mathrm{81.6-90.2} \mathrm{and} \mathrm{Al}_{2} \mathrm{O}_{3}$ 2.36.4 wt.\% the latter). Finally, clinopyroxenes in Southern Patagonian dunites, orthopyroxenites, and clinopyroxenites (Fig. 2f) plot mainly on a low $\mathrm{Al}_{2} \mathrm{O}_{3} / \mathrm{Mg} \#$ trend (Mg\# 83.7-94.1; $\mathrm{Al}_{2} \mathrm{O}_{3}$ 1.4-4.0 wt.\%), even though some samples are typified by a higher $\mathrm{Al}_{2} \mathrm{O}_{3}$ content (3.7-8.8 wt.\%) in a narrower Mg\# interval (90.9-92.9).

Orthopyroxenes from Northern, Central, and Southern Patagonia harzburgites and lherzolites (Fig. 3) have features similar to the coexisting clinopyroxenes. Orthopyroxene from Northern Patagonia are characterized by $\mathrm{Mg \#}$ varying between 88.0 and 93.7 and $\mathrm{Al}_{2}{ }^{\prime} J_{3}$ ':etween 0.7 and 6.1 wt.\%, which is quite comparable to those from Central Patagonian xennlla's ( $\mathrm{Mg \#} \mathrm{87.5-93.0} \mathrm{and} \mathrm{Al}_{2} \mathrm{O}_{3}$ 0.1-6.3 wt.\%). With respect to their clinopyroxenes, which arf a. oned on a single $\mathrm{Al}_{2} \mathrm{O}_{3}$ vs. $\mathrm{Mg \#}$ trend, orthopyroxenes from Northern Patagonia lie on $\mathrm{t} v \mathrm{dir}$ crete trends; one of these, typified by lower $\mathrm{Al}_{2} \mathrm{O}_{3} / \mathrm{Mg} \#$ ratio, is represented mainly $v$ Cerro Aznares harzburgites (Fig. 3a). Analogous considerations can be made for Central ' ' tagonia, where a low $\mathrm{Al}_{2} \mathrm{O}_{3} / \mathrm{Mg} \#$ trend mostly typifies orthopyroxenes in Estancia Sol de Mrvo hr czburgites and lherzolites (Fig. 3b). Southern Patagonian orthopyroxenes behave similarly $\mathrm{t}$ the coexisting clinopyroxenes, with a $\mathrm{Mg} \#$ of 87.3-92.2 and $\mathrm{Al}_{2} \mathrm{O}_{3}$ mostly ranging between 2.0 and ${ }^{1} 6$ wt.\%. An exception is seen in some Tres Lagos samples, in which orthopyroxene reaches $\mathrm{Al}_{\llcorner} \mathrm{T}_{3}$ contents up to $5.8 \mathrm{wt}$ \% (Fig. 3c). Clinopyroxene and orthopyroxene from Northern Patagonia dunites and websterites (Fig. 3d) lie on two discrete trends, typified by lower and higher $\mathrm{Al}_{2} \mathrm{O}_{3} / \mathrm{Mg} \#$ ratios $\left(\mathrm{Mg} \#\right.$ 80.4-88.3 and $\mathrm{Al}_{2} \mathrm{O}_{3}$ 1.2-3.6 wt.\% and $\mathrm{Mg} \#$ 89.8-91.6 and $\mathrm{Al}_{2} \mathrm{O}_{3}$ 3.4-4.6 wt.\%, respectively). Orthopyroxenes from Central Patagonian dunites, wehrlites, websterites, and clinopyroxenites (Fig. 3e) have similar features except for the wider $\mathrm{Al}_{2} \mathrm{O}_{3}$ interval (from 1.6 up to 5.9 wt.\%). In addition, orthopyroxenes from Southern Patagonian dunites and orthopyroxenites (Fig. 3f) can be subdivided into two distinct groups with different $\mathrm{Al}_{2} \mathrm{O}_{3} / \mathrm{Mg \#}$ ratios (Mg\# 80.7-88.0 and $\mathrm{Al}_{2} \mathrm{O}_{3}$ 2.0-4.6 wt.\% and $\mathrm{Mg \#}$ 89.8-90.7 and $\mathrm{Al}_{2} \mathrm{O}_{3}$ 2.4-3.6 wt.\%, respectively). 
Likewise pyroxenes, olivine from Northern and Central Patagonia harzburgites/lherzolites is characterized by similar composition, with forsterite (Fo) content ranging from 89.2 to 91.9 and from 88.1 to 92.0 , respectively. $\mathrm{NiO}$ content ranges between 0.26 and $0.50 \mathrm{wt} \%$ in both Northern and Central Patagonia samples. Olivine from Southern Patagonia localities is characterized by a narrower Fo interval (88.0-91.3) and a wider $\mathrm{NiO}$ range (0.27-0.57 wt.\%; Fig. 4).

Olivines in Northern Patagonia dunites and websterites are generally similar to those from harzburgites and lherzolites (Fo 89-90; $\mathrm{NiO}$ 0.32-0.4 wt.\%; Fig. 4a), except for a few crystals, which are characterized by lower Fo ( 86) at comparable $\mathrm{NiO}$ content $(0.3 n-\iota .32$ wt.\%). A complete overlap between harzburgites/lherzolites and dunites, wehrlites, a 14 websterites is shown in Central Patagonian olivines, which have Fo 89-91 at $\mathrm{NiO}$ rangino : atween 0.21 and 0.45 wt.\% (Fig. 4b). Olivine from Southern Patagonia dunites and orthopyrox nites are generally less magnesian that those from harzburgites/lherzolites, having Fo be'w 2 n 86 and 90 and $\mathrm{NiO}$ comprised between 0.28 and 0.44 wt.\% (Fig. 4c).

To estimate the depletion and enrichment pircesses (melt extraction and metasomatism) that occurred in the SCLM beneath Patagonia, a or n urison between trace element concentration and $\mathrm{Al}_{2} \mathrm{O}_{3}$ content of clinopyroxene in both eridutitic and pyroxenitic xenoliths was performed. In Fig. 5, the behaviour of chondrite-normah ${ }^{\circ}$ d (Sun and McDonough, 1989) $\mathrm{La} / \mathrm{Yb}$ ratio and $\mathrm{Sr}$ (hereafter $(\mathrm{La} / \mathrm{Yb})_{\mathrm{N}}$ and $\mathrm{Sr}_{\mathrm{N}}$, respect, $\cdot \mathrm{ly}$, in clinopyroxenes is correlated to their $\mathrm{Al}_{2} \mathrm{O}_{3}$ content.

A group of clinopyroxenes is characterized by light rare earth elements (LREE) enrichment (increase in the $(\mathrm{La} / \mathrm{Yb})_{\mathrm{N}}$ ratio) coupled with $\mathrm{Al}_{2} \mathrm{O}_{3}$ depletion (Fig. 5a). This behaviour is observable in Northern, Central, and Southern Patagonia localities (Cerro Mojon, Prahuaniyeu, Paso de los Indios, Cerro de los Chenques, Don Camilo, Estancia Sol de Mayo, Cerro Fraile, and Pali Aike). However, a positive correlation between LREE and $\mathrm{Al}_{2} \mathrm{O}_{3}$ content is displayed by clinopyroxenes from Cerro Rio Chubut and Gobernador Gregores (Fig. 5b), although some samples from these localities "flatten" at around $(\mathrm{La} / \mathrm{Yb})_{\mathrm{N}}=10$. Some localities do not display a clear correlation between LREE and $\mathrm{Al}_{2} \mathrm{O}_{3}$ : this is the case of Estancia Alvarez, Cerro Aznares, Cerro Chenque, Puesto Diaz, Comallo, Cerro 
Clark, Cero Cuadrado, Tres Lagos and Las Cumbres (Fig. 5c). A general correspondence between $\mathrm{Sr}_{\mathrm{N}}$ and $(\mathrm{La} / \mathrm{Yb})_{\mathrm{N}}$ vs. $\mathrm{Al}_{2} \mathrm{O}_{3}$ diagrams could be observed, notwithstanding that the $\mathrm{Sr}_{\mathrm{N}}$ trends are less marked than the $(\mathrm{La} / \mathrm{Yb})_{\mathrm{N}}$ ones (Fig. 5d-e-f). Exceptions are constituted by few localities from Northern and Southern Patagonia (Cerro Aznares, Cerro Chenque, Puesto Diaz, Comallo, and Tres Lagos) - which show a positive correlation between $\mathrm{Sr}_{\mathrm{N}}$ and $\mathrm{Al}_{2} \mathrm{O}_{3}$ but a scattered $\mathrm{REE}$ distribution and by Cerro Fraile, where there is no correlation between $\mathrm{Sr}_{\mathrm{N}}$ and $\mathrm{Al}_{2} \mathrm{O}_{3}$.

\subsection{Results: Sr-Nd isotopes}

The new Sr-Nd isotopic compositions of clinopyroxene sepr ians rrom 29 Patagonia xenoliths are reported in Table 1 and Fig. 6. All samples are aligned long the mantle array (DePaolo and Wasserburg, 1979) and are characterized by ${ }^{87} \mathrm{Sr} /{ }^{86} \mathrm{Sr}_{\text {. }}$. nging from 0.7027 to 0.7043 and by ${ }^{143} \mathrm{Nd} /{ }^{144} \mathrm{Nd}$ between 0.51269 and 0.51309 . Clinory $\mathrm{xe}$. les from Cerro Rio Chubut and Estancia Sol de Mayo lie on a narrow interval, characterik ${ }^{\prime} d$ sy a high $\mathrm{Sr}$ isotopic signature $\left({ }^{87} \mathrm{Sr} /{ }^{86} \mathrm{Sr}\right.$ from 0.7037 to $0.7039 ;{ }^{143} \mathrm{Nd} /{ }^{144} \mathrm{Nd}$ from 0.51269 to $\left.0 . .21279\right)$. Cerro Fraile, Gobernador Gregores and Pali Aike clinopyroxenes have similar $\mathrm{Sr}-\mathrm{Nd}$ isot ${ }_{\mathrm{r}} \mathrm{c}$ signatures, with ${ }^{87} \mathrm{Sr} /{ }^{86} \mathrm{Sr}$ generally falling between 0.7030 and 0.7035 and ${ }^{143} \mathrm{Nd} /{ }^{144} \mathrm{~N} \mathrm{t}$ in lie range $0.51281-0.51299$. The $\mathrm{Sr}-\mathrm{Nd}$ isotopic range of Cerro de los Chenques and Cerro $\mathcal{C}^{\mathbf{l}^{1} r_{K}}$ clinopyroxenes is wider, covering the entire ${ }^{87} \mathrm{Sr} /{ }^{86} \mathrm{Sr}$ and ${ }^{143} \mathrm{Nd} /{ }^{144} \mathrm{Nd}$ interval (Fig. C)

The $\mathrm{Sr}-\mathrm{Nd}$ isotopic signature of all the analysed samples is comparable to that of clinopyroxene separates from other Patagonian localities (Bjerg et al., 2009; Gorring and Kay, 2000; Mundl et al., 2015, 2016; Rivalenti et al., 2007; Fig. 6), lying between the depleted mantle (DMM; Workman and Hart, 2005) and the enriched mantle end-members (EM I, Zindler and Hart, 1986; EM II, Hart, 1988). No systematic variations in the ${ }^{87} \mathrm{Sr} /{ }^{86} \mathrm{Sr}$ and ${ }^{143} \mathrm{Nd} /{ }^{144} \mathrm{Nd}$ ratios between Northern, Central, and Southern Patagonia xenoliths were identified (Fig. 6), even though Gobernador Gregores, Cerro Fraile and Pali Aike samples have similar signatures, which are generally more depleted than the rest of the Central Patagonia samples (Cerro Clark and Estancia Sol de Mayo). The correlation between 
the analysed samples and the compositional fields of Northern, Central and Southern Patagonia mantle xenoliths reported in literature (Bjerg et al., 2009; Gorring and Kay, 2000; Mundl et al., 2015, 2016; Rivalenti et al., 2007) is total (Fig. 6). Overall, a wider Sr-Nd isotopic range characterizes Central and Southern Patagonia $\left({ }^{87} \mathrm{Sr} /{ }^{86} \mathrm{Sr}=0.7023-0.7059 ;{ }^{143} \mathrm{Nd} /{ }^{144} \mathrm{Nd}=0.51223-0.51328\right)$ with respect to Northern Patagonia $\left({ }^{87} \mathrm{Sr} /{ }^{86} \mathrm{Sr}=0.7027-0.7048 ;{ }^{143} \mathrm{Nd} /{ }^{144} \mathrm{Nd}=0.51262-0.51313\right)$.

\section{Depletion and enrichment processes beneath Patagonia}

In the following sections, a compilation of previously published daı has been used to model and review the depletion and enrichment (metasomatism and refer all ? tion) processes acting throughout the Northern, Central and Southern Patagonian SCLM. Tn ` htain comparable results, the extent of depletion was evaluated by applying major/trace elemen clinopyroxene (Bonadiman and Coltorti, 2011; U`te . e. al., 2011; Zou, 1998) from harzburgites and lherzolites. Analogously, common criteria w re adopted to estimate the enrichment processes recorded by clinopyroxene (see below). s summary of the compositional features of the xenoliths and a list of the obtained results are given $i$. Table 2.

\subsection{Melt extraction processes}

The extent of depletion ev. $n_{\mathrm{s}}$ related to melt extraction was estimated through the major element ( $\mathrm{MgO}$ and $\mathrm{Al}_{2} \mathrm{O}_{3}$ ) composition of orthopyroxene and clinopyroxene (Bonadiman and Coltorti, 2011; Upton et al., 2011) and the trace element (Y and $\mathrm{Yb}$ ) concentration of clinopyroxene (Zou, 1998). All these models work in the spinel stability field; therefore, the garnet-bearing harzburgites and Therzolites documented in two Patagonian localities (Prahuaniyeu and Pali Aike; Bjerg et al., 2009) were not taken into account. For these localities, only the spinel-bearing lithotypes were considered to model the depletion processes affecting these SCLM domains. In those samples where the amount of melt extraction recorded by orthopyroxene exceeded $25 \%$, clinopyroxene was not considered to estimate the degree of melt extraction. Indeed, its presence in mantle residua after $25 \%$ partial melting 
is unlikely (Scott et al., 2016; Walter, 2003) and the coexistence between Mg-rich orthopyroxene and clinopyroxene in some samples may be the result of subsequent metasomatic/refertilisation processes.

\subsubsection{Depletion processes modelled through major elements}

In Fig. 7 the $\mathrm{Al}_{2} \mathrm{O}_{3}$ content of orthopyroxene from Northern, Central, and Southern Patagonia harzburgites and therzolites is plotted against $\mathrm{MgO}$. A large variability of the partial melting degree $(F \%)$ characterizes all the Patagonian mantle portions. In Northern Patagonia (Fig. 7a), orthopyroxene from Estancia Alvarez records an $F$ of 29-30\%, whereas Cerro Chenc e, Puesto Diaz, and Comallo samples display an $F$ between 21 and 31\%. Partial melting tes $_{z}$ ees of the spinel-bearing samples from Prahuaniyeu range between 10 and 23\%. On the othe side, Cerro Rio Chubut, Cerro de los Chenques, and Coyhaique record $F$ values up to $30 \%(11-, 1 \%, 14-27 \%$ and $27-30 \%$, respectively).

Central Patagonian orthopyroxenes (Fig. 7b) recc a ne following $F$ ranges: $23-26 \%$ at Chile Chico, 12-17\% at Cerro Clark, $19-30 \%$ at Estancia ${ }^{\prime} \mathrm{o}$ de Mayo, 22-27\% at Auvernia, $8-31 \%$ at Gobernador Gregores, and 13-24\% at Cerro Cuadrado and Cerro Redondo. In Southern Patagonia (Fig. 7c), the depletion event recorded by Tres Låns $\cdots$ thopyroxenes are characterized by a wide $F$ range (1030\%), whereas those modelled fo: Cerıo Fraile and Las Cumbres are quite similar (13-26\% and 1725\%, respectively). Finally, Paı 4 i ie orthopyroxene records an $F$ value between 12 and $18 \%$ (Table 2).

Clinopyroxene $\mathrm{Al}_{2} \mathrm{O}_{3}$ vs. $\mathrm{MgO}$ content and the related melt extraction models are shown in Fig. 8. In Northern Patagonia (Fig. 8a), clinopyroxene from Cerro Chenque, Puesto Piaz, Comallo, and Cerro Mojon samples record an $F$ ranging between 17 and 21\%. Clinopyroxene in the spinel-bearing samples of Prahuaniyeu record a highly variable $F$ range, between 7 and $25 \%$. Similar features are displayed by Cerro Rio Chubut and Cerro de los Chenques samples ( $F=6-17 \%$ and 10-22\%, respectively). Paso de los Indios clinopyroxenes record a narrower $F$ range $(F=17-21 \%)$. According to clinopyroxene REE distributions, many of these localities (Cerro Mojon, Comallo, Prahuaniyeu, Cerro Rio Chubut, and Cerro de los Chenques) were subjected to slight to significant subsequent 
enrichment processes (see below). Consequently, some of their lower $F$ values (6-10\%) could be affected by the action of metasomatic/refertilisation processes that may have overprinted the pristine depletion signature. In Central Patagonia (Fig. 8b), clinopyroxenes from Chile Chico, Cerro Clark, Don Camilo, Cerro Cuadrado, and Auvernia record similar melt extraction events, with $F$ generally ranging between 10 and 17\%. Estancia Sol de Mayo clinopyroxenes experienced greater melt extraction $(F=17-21 \%)$ and the highest values are comparable to those of Gobernador Gregores and Cerro Redondo, whose $F$ ranges are wider (3-22\% and $8-22 \%$, respectively). The occurrence of subsequent enrichment processes was also particularly efficient in su. ne Central Patagonian SCLM domains (Cerro Clark, Estancia Sol de Mayo and Gobernador u 'gores, see below); therefore, most of the low $F$ values calculated (especially those < 10\%) shnui ${ }^{\top}$ be considered with caution. Southern Patagonian clinopyroxenes (Fig. 8c) record large $F$ intarv.'s: between 9 and 19\% at Tres Lagos, between 12 and $23 \%$ at Cerro Fraile, and betweer ; an $25 \%$ in the spinel-bearing xenoliths of Pali Aike. A narrow $F$ range is modelled for th Lrs Cumbres samples, which yield a value of 17-18\%. With respect to the Northern and Central 1 oions, Southern Patagonia was less pervasively affected by subsequent enrichment processes (se - Jelow), therefore, the $F$ values calculated for the latter (except those obtained for some Serı Fraile and Pali Aike samples) could be considered more reliable than those for the forme.

\subsubsection{Depletion processes modelled through trace elements}

Clinopyroxene trace element modelling (Fig. 9), developed by means of the PM-normalized (Sun and McDonough, 1989) Y vs. Yb diagram of Zou (1998), confirms the large variability in the partial melting degree affecting the Patagonian SCLM. In Northern Patagonia (Fig. 9a), an $F$ of $\sim 14 \%$ is obtained from Cerro Chenque clinopyroxene, whereas Puesto Diaz, Comallo, Cerro Mojon, and Prahuaniyeu samples record an $F$ between 6 and 20\%. Highly variable ranges are recorded by Cerro Rio Chubut and Cerro de los Chenques samples $(F=1-10 \%$ and $3-15 \%$, respectively), whereas Paso de los Indios xenoliths yield almost constant values $(F=13-14 \%)$. Few data are available for Central 
Patagonia (Fig. 9b), where clinopyroxene trace element concentration records $F$ between 1 and $8 \%$ at Cerro Clark, Don Camilo and Cerro Cuadrado, whereas a higher range is obtained from the Gobernador Gregores samples $(F=3-17 \%)$. The melt extraction recorded by clinopyroxene is quite variable in Southern Patagonia, where $F$ ranges from 1 to $14 \%$ at Tres Lagos, 4 to $21 \%$ at Cerro Fraile, 5 to $12 \%$ at Las Cumbres and 2 to $24 \%$ in Pali Aike spinel-bearing samples (Fig. 9c).

\subsection{Enrichment processes}

As already described in section 4.1, a widespread negative correlatinn 'vetween $\operatorname{Sr}_{\mathrm{N}}$ and $(\mathrm{La} / \mathrm{Yb})_{\mathrm{N}}$ and $\mathrm{Al}_{2} \mathrm{O}_{3}$ is also present in many Patagonian localities such as $\mathrm{Cen}_{\mathrm{n}}$ Mojon, Prahuaniyeu, Paso de los Indios, Cerro de los Chenques, Don Camilo, Estancia sol te Mayo, and Pali Aike (Fig. 5a and 5d). This feature is consistent with the occurrence of enricht.'nt processes able to modify the trace element composition of the clinopyroxenes after a ne'. extraction event ( $\mathrm{Al}_{2} \mathrm{O}_{3}$ depletion). In this case, the amount of melt/fluid interacting $w^{\text {th }}$.ne previously depleted clinopyroxene was relatively small, hence leading to identify this enrich.^nt process as "metasomatism".

However, a positive correlation betwreet. $\mathrm{l}_{2} \mathrm{O}_{3}$ and both $(\mathrm{La} / \mathrm{Yb})_{\mathrm{N}}\left(\right.$ Fig. 5b) and $\mathrm{Sr}_{\mathrm{N}}($ Fig. 5e) is displayed by some Cerro Rio Chu': 'it aıd Gobernador Gregores samples, even though many of them are typified by an $\mathrm{Al}_{2} \mathrm{O}_{3}$ increas a. nearly constant $(\mathrm{La} / \mathrm{Yb})_{\mathrm{N}}$ and $\mathrm{Sr}_{\mathrm{N}}$ values. A positive correlation between $\mathrm{Al}_{2} \mathrm{O}_{3}$ and $\mathrm{SrN}_{\mathrm{L}}$ ? typifies samples from other Patagonian localities, and is particularly evident for Tres Lagos (Fig. 5e). Such a positive correlation between trace elements and $\mathrm{Al}_{2} \mathrm{O}_{3}$ can be interpreted in two different ways; these are functions of two opposite processes affecting the SCLM. The first is melt extraction, which would result in a decrease in both $(\mathrm{La} / \mathrm{Yb})_{N}$ and $\operatorname{Sr}_{N}$ together with $\mathrm{Al}_{2} \mathrm{O}_{3}$. The second is a significant enrichment, which could restore the initial concentration of these trace elements simultaneously with $\mathrm{Al}_{2} \mathrm{O}_{3}$ increase. This latter process, previously defined as "refertilisation", would necessitate high melt (or fluid)/rock ratios or, alternatively, longer interaction time between the mantle domain and the percolating melt, capable of obliterating the previous depletion features and restoring a fertile composition. This is the case for 
Gobernador Gregores xenoliths where significant modal amounts of amphibole and phlogopite formed during a pervasive enrichment process subsequent to a melt extraction event (up to $31 \% \mathrm{~F}$ according to orthopyroxene major element composition).

In some Northern, Central, and Southern Patagonia localities, neither a positive nor a negative correlation between trace elements and $\mathrm{Al}_{2} \mathrm{O}_{3}$ content of clinopyroxene was noticed. This behaviour, typical of mantle xenoliths from Estancia Alvarez, Cerro Cuadrado, and Las Cumbres (Figs. 5c and 5f), represents a third kind of SCLM evolution. After a melt extraction event that depleted clinopyroxene in both $\mathrm{Al}_{2} \mathrm{O}_{3}$ and trace elements, the circulation of va-iable amounts of fluids/melts re-added to the system incompatible elements and LREE. Th $s$..eIf-rock interaction, however, was unable to restore the $\mathrm{Al}_{2} \mathrm{O}_{3}$ content of clinopyroxene and the - fore, to re-build a fertile composition and the high $(\mathrm{La} / \mathrm{Yb})_{\mathrm{N}}$ and $\operatorname{Sr}_{\mathrm{N}}$ values suggest that ? 1. tasomatic event, rather than complete refertilisation, followed the partial melting.

\section{Timing and distribution of the depletin and enrichment processes in the Patagonian SCLM}

\subsection{Mantle components}

The application of mixing models equacion B.7 in Appendix B) to the $\mathrm{Sr}$ and $\mathrm{Nd}$ systematics enabled us to establish in what proportu $\urcorner s$ the DMM, EM I, and EM II reservoirs contributed to generating the isotopic signature of the Patagonian SCLM (Fig. 10). A first model was developed by considering possible mixing between the DMM (Workman and Hart, 2005) and the EM I (Zindler and Hart, 1986) mantle components, adopting the same parameters used by Kay et al. (2013) for modelling the source of Patagonian plateau lavas. Afterwards, two different mixing models between DMM and an EM II component $\left({ }^{87} \mathrm{Sr} /{ }^{86} \mathrm{Sr}=0.7075 ;{ }^{143} \mathrm{Nd} /{ }^{144} \mathrm{Nd}=0.51263 ; \mathrm{Nd}=54.5 \mathrm{ppm} ;\right.$ Hart, 1988) were advanced by varying the $\mathrm{Sr}$ concentration of the latter from 750 to $140 \mathrm{ppm}$ (changing its $\mathrm{Sr} / \mathrm{Nd}$ ratio from 13.8 to 2.6). Results showed that all Patagonian samples have scattered distributions, plotting between the DMM-EM I and the DMM-EM II mixing trends (Fig. 10) and thus further confirming a variably efficient role played by the enrichment processes in obliterating the pristine signature (Fig. 10a). The 
xenoliths have Sr-Nd isotopic ratios comparable to those of the Patagonian plateau lavas $\left({ }^{87} \mathrm{Sr} /{ }^{86} \mathrm{Sr}=\right.$ $0.7031-0.7053 ;{ }^{143} \mathrm{Nd} /{ }^{144} \mathrm{Nd}=0.51248-0.51293$ ), whose signature was ascribed to mixing processes between DMM and both EM I and EM II components (i.e. Gorring et al., 2003; Kay et al., 2013). According to Gorring et al. (2003), the EM II-like contribution could be ascribed to the addition of sediments and/or fluids to the Patagonian SCLM during Phanerozoic subduction processes, whereas the EM I-like component could have been generated by the infiltration of ocean island basalts (OIB)type pulses into the mantle during Gondwana breakup and Cenozoic magmatism. By contrast, Kay et al. (2013) hypothesized that the EM I component represents the incorporation of continental lithosphere into the mantle source by lithospheric and crus d tetachment, sediment subduction, and/or forearc erosion. As shown in Fig. 10a, Patagonian xe - liths plot close to both the DMM-EM I and DMM-EM II mixing curves, without showing any $\mathrm{p}_{\mathrm{r}}$ ferential alignment as functions of their geographical provenance and/or age of extraction ( $\mathrm{s}$. T.Jble 2). As observed by Gorring et al. (2003), for some post-plateau lava, it is quite diffic - $^{-}$tr determine whether the enriched component is EM Ior EM II-type. The Sr-Nd isotopic signature of most of the Northern, Central, and Southern Patagonia xenoliths could be explained by mixins $b$ treen 94-99\% DMM and 1-5\% EM II (at 140 ppm Sr), or, alternatively, between $>99 \%$ DN: $M$ and $<1 \%$ EM-I components. It should be noted that a good alignment is observed for webstc iti,/wehrlitic samples, irrespective of their geographical provenance (Fig. 10b). In contrast with the widespread dispersion of therzolites and harzburgites, websterites and wehrlites plot along the mixing trend between DMM and EM II (at $140 \mathrm{ppm} \mathrm{Sr}$ ), suggesting that the involvement of $1-5 \%$ of an EM II component is more likely to explain their genesis (Fig. 10b).

\subsection{Timing of melt extraction from Northern to Southern Patagonia}

Notwithstanding the similar $\mathrm{Sr}-\mathrm{Nd}$ isotopic signature and the highly variable composition, Patagonia mantle xenoliths show systematic geochemical features and provide precise information about the distribution of depletion/enrichment processes in the SCLM wedge. On the basis of bulk rock Re-Os systematics, several authors proposed a strongly heterogeneous nature for the SCLM beneath 
Patagonia (Mundl et al., 2015, 2016; Schilling et al., 2008, 2017). According to these authors, the lithosphere beneath Patagonia is composed of several portions that experienced variable depletion events at different times since the Palaeoproterozo ic $(<2.5 \mathrm{Ga})$. Their original depletion signature was at least partially obscured by subsequent enrichment processes, among which those related to the Mesozoic to present-day Andean subduction and the Cenozoic magmatism are certainly the best preserved and identifiable.

If we compare the averaged partial melting degree recorded by orthopyroxene major elements $\left(\mathrm{Al}_{2} \mathrm{O}_{3}\right.$ and $\mathrm{MgO}$ ) with the latitude of the various localities (Fig. 11a). a cirrease in F from ca. $30 \%$ in Northern Patagonia to ca. $15 \%$ in the Southern regions is obsf iv t. A comparable trend is displayed by clinopyroxene (from $F$ ca. $25 \%$ in Northern Patagonia tr ca $16 \%$ in Southern Patagonia; Fig. 11b). Average partial melting degrees recorded by clinopyroyen trace elements are slightly lower than those obtained by major elements modelling, rancii, fom ca. $15 \%$ in the Northern localities to ca. 7-12\% in the Central/Southern ones (Fig. 11). Consistently, the average Fo content of olivine decreases from 90.0-91.6 in Northern Pata 'nia to 89.1-90.7 in Southern Patagonia (Fig. 11d). Since the Northern Patagonia xenoliths rerned no, the highest melt extraction degrees are brought to the surface by the most recent magm ic tpisodes (1-5 Ma; Fig. 11f; Table 2), we cannot exclude that they could represent fragments $\mathrm{c}^{\mathrm{f}} \mathrm{t}^{\mathrm{l}} \mathrm{e}$ SCLM bearing witness to the previous melting event, linked to tholeiite production during the inain plateau phase at Somoncura (i.e. 20\% F; Kay et al., 2007).

A positive correlation can be also found between latitude and the average $\mathrm{T}_{\mathrm{RD}}(\mathrm{Re}-\mathrm{Os})$ age obtained for each Patagonian locality (Mundl et al., 2015, 2016; Schilling et al., 2008, 2017; Fig. 11e), suggesting that the Southern Patagonia SCLM domains experienced minor melt extractions in older times with respect to the Northern Patagonia region. No correlation between latitude and $\mathrm{Sr}-\mathrm{Nd}$ isotopic signature of the mantle xenoliths can be envisaged, probably because of the obliterating action of the recent enrichment processes. Analogously, the trace element ( $\mathrm{REE}$ and $\mathrm{Sr}$ ) and $\mathrm{Al}_{2} \mathrm{O}_{3}$ contents in clinopyroxene show no link with latitude, as evidenced by the variable occurrence of both positive and negative correlations in the Northern, Central, and Southern Patagonia localities (Fig. 5). 


\subsection{Nature and timing of the enrichment processes}

In this section, the major/trace element composition of clinopyroxenes from Northern, Central and Southern Patagonia wehrlites, websterites, orthopyroxenites and clinopyroxenites (Fig. 12) is considered to speculate about the enrichment processes and their distribution in the Northern, Central and Southern Patagonia SCLM domains. Clinopyroxenes from Northern Patagonia websterites can be subdivided into two distinct groups. The first one is characterized by high $\mathrm{Al}_{2} \mathrm{O}_{3} / \mathrm{Mg} \#$ ratio (Fig . 12a) and LREE-depleted patterns (Fig. 12b) and is composed of Ceru de los Chenques websterites. The second one has lower $\mathrm{Al}_{2} \mathrm{O}_{3} / \mathrm{Mg} \#$ ratios (Fig. 12a), relativ -1y depleted heavy rare earth elements (HREE) and flat to slightly LREE-enriched patterns and mon rises Cerro Aznares, Prahuaniyeu and Cerro Rio Chubut websterites (Fig. 12c). Clinopyroxenfs n the few Central Patagonia websterites (Cerro Clark and Gobernador Gregores) lie on ${ }^{~} h h h_{i} h_{h} \mathrm{Al}_{2} \mathrm{O}_{3} / \mathrm{Mg} \#$ trend (Fig. 12a). Their REE patterns vary from slightly LREE-depleted, ${ }^{\text {hur }}$ comparable to clinopyroxene in Northern Patagonia

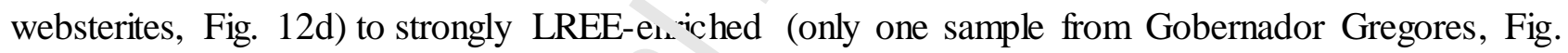
12e). Clinopyroxenes in Central Patamoni. linopyroxenites and wehrlites (Cerro Clark, Estancia Sol de Mayo and Gobernador Gregor s) Lelong to both the high $\mathrm{Al}_{2} \mathrm{O}_{3} / \mathrm{Mg \#}$ and the low $\mathrm{Al}_{2} \mathrm{O}_{3} / \mathrm{Mg} \#$ groups (Fig. 12a). The REE $\mathrm{b}^{\text {ta }}$ ns of Cerro Clark clinopyroxenites are generally depleted and similar to those of the con ${ }^{2}$ Spunding websterites (Fig. 12d). Clinopyroxenes from Estancia Sol de Mayo and Gobernador Gregores wehrlites, however, have the most LREE-enriched and convexupward patterns (Fig. 12e). Clinopyroxenes from Southern Patagonia clinopyroxenites (Cerro Fraile) generally fall in a narrow $\mathrm{Al}_{2} \mathrm{O}_{3}-\mathrm{Mg \#}$ interval (Fig. 12a) and have flat REE profiles (Fig. 12f). Clinopyroxenes from Southern Patagonia orthopyroxenites (Cerro Fraile) plot on the low $\mathrm{Al}_{2} \mathrm{O}_{3} / \mathrm{Mg} \#$ trend (Fig. 12a) and are slightly LREE-enriched, with respect to the corresponding clinopyroxenites, at comparable HREE contents (Fig. 12g).

According to Dantas (2007) and Melchiorre et al. (2015), the LREE-depleted pattern of clinopyroxenes from Northern Patagonia websterites belonging to the high $\mathrm{Al}_{2} \mathrm{O}_{3} / \mathrm{Mg} \#$ group provide 
the evidence for percolation of tholeiitic-like melt in the Patagonian SCLM. Consistently, clinopyroxenes from therzolites/harzburgites are aligned on the high $\mathrm{Al}_{2} \mathrm{O}_{3} / \mathrm{Mg} \#$ enrichment trend (Fig. 2), further suggesting that a tholeiitic-like melt infiltrated the mantle domains. These findings are consistent with those of D’Orazio et al. (2000), Gorring et al. (2003), and Kay et al. (2007; 2013), who recognized the existence of a tholeiitic main plateau stage in the Somoncura region. In contrast, the LREE-enriched patterns of clinopyroxenes with lower $\mathrm{Al}_{2} \mathrm{O}_{3} / \mathrm{Mg} \#$ ratios are ascribable to the percolation of a $\mathrm{CaO}$-rich and $\mathrm{SiO}_{2}$-undersaturated, transitional to alkaline melt in the SCLM. The alkaline-like enrichment was not efficient enough to eradicate the nrisine depletion event in terms of major elements. The alkaline event was preserved only as som, L'EE-enriched patterns of refractory clinopyroxenes (harzburgites and lherzolites at Cerro $M_{\curvearrowleft} \mathfrak{n}$, Comallo, Prahuaniyeu, Cerro Rio Chubut, and Cerro de los Chenques). The occurrence of aln ?line melts has been widely documented throughout this region, especially during the post-1 atf au magmatic stages (D'Orazio et al., 2000; Kay et al., 2007; 2013).

The bimodal occurrence of tholeiitic and lkaline enrichment processes is also evidenced beneath Central Patagonia, where clinopyroxene fr'm lherzolites/harzburgites plot along both the high and low $\mathrm{Al}_{2} \mathrm{O}_{3} / \mathrm{Mg \#}$ trends (Fig. 2). This is also suggested by the occurrence of LREE-depleted clinopyroxenes with high $\mathrm{Al}_{2} \mathrm{O}_{3},{ }^{\prime} \mathrm{M}_{2}$ \# in Cerro Clark websterites and LREE-enriched clinopyroxe nes with low $\mathrm{Al}_{2} \mathrm{O}_{3} / \mathrm{Mg} \#$ in Es. 'ncid Sol de Mayo and Gobernador Gregores wehrlites. However, some clinopyroxenes from Estancia Sol de Mayo and Gobernador Gregores wehrlites have "intermediate" geochemical features, with high $\mathrm{Al}_{2} \mathrm{O}_{3} / \mathrm{Mg \#}$ ratios but LREE-enriched profiles. These features are possibly consistent with the infiltration of transitional affinity melts in the SCLM. As already highlighted by Melchiorre et al. (2015), a transitional-type agent percolating through the mantle is capable of moving above and below the saturation threshold, as a function of orthopyroxene reaction/dissolution or crystallization at the expense of olivine or as a newly forming phase (Arai et al., 2006). 
Broadly speaking, $(\mathrm{La} / \mathrm{Yb})_{\mathrm{N}}$ and $\mathrm{Sr}_{\mathrm{N}}$ enrichment - concomitant with $\mathrm{Al}_{2} \mathrm{O}_{3}$ depletion of clinopyro xe ne - are evidence of a metasomatic process (lower melt/rock ratio) and recorded in many localities of Northern and Central Patagonia. A refertilisation event (simultaneous trace element and $\mathrm{Al}_{2} \mathrm{O}_{3}$ enrichment) occurred instead in the SCLM portions beneath Cerro Rio Chubut and Gobernador Gregores, where large amounts of hydrous melt interacted with the previously depleted mantle, leading to the formation of significant modal amphibole and phlogopite. In this framework, the rare presence of websteritic xenoliths with both low and high $\mathrm{Al}_{2} \mathrm{O}_{3} / \mathrm{Mg \#}$ and LREE-enriched clinopyroxenes in Northern/Central Patagonia could bear witness of both a (first) tholeiitic refertilisation and a (second) alkaline metasomatism, slv ving two subsequent processes characterized by progressively decreasing melt/rock ratio Further evidence of the action of metasomatic and refertilisation processes could be provied by the $\mathrm{Sr}-\mathrm{Nd}$ isotopic systematics. Irrespective of their geographical provenance, $c_{i}$ or yroxenes belonging to refertilised SCLM portions (with positive correlation between rar - elements and $\mathrm{Al}_{2} \mathrm{O}_{3}$ content) are generally depleted in ${ }^{87} \mathrm{Sr} /{ }^{86} \mathrm{Sr}$ with respect to those belongiı- to the metasomatized suites, suggesting an interaction with melts derived from a source with high ar asthenospheric contribution (Fig. 10c). Altogether, these data suggest that the SCLM portio: : beneath Cerro Rio Chubut (Northern Patagonia) and Gobernador Gregores (Central Patagonia) na have experienced both tholeiitic refertilisation and alkaline metasomatism.

In Southern Patagonian Iherzolites/harzburgites, no evidence of tholeiitic and/or alkaline enrichment is generally provided by the major/trace element distribution of clinopyroxene, which lies at narrow $\mathrm{Al}_{2} \mathrm{O}_{3}$ and $\mathrm{Mg \#}$ intervals (Fig. 2), thus confirming that melt extraction was the main process acting in the SCLM (Ntaflos et al., 2007). Similar behaviour characterizes clinopyroxene from clinopyroxenites (Fig. 12a). An exception is constituted by a few Pali Aike samples, where the moderate LREE-enrichment of clinopyroxene probably occurred due to the interaction with alkaline agents. A spatially limited involvement of $\mathrm{SiO}_{2}$-saturated melts is instead suggested by Cerro Fraile 
orthopyroxenites, whose formation was ascribed to the percolation of proto-adakitic agents into the mantle wedge sectors closer to the trench (Faccini et al., 2013).

\section{Conclusions}

In this work, a review of the main geochemical features of all Patagonian mantle xenoliths, together with new $\mathrm{Sr}-\mathrm{Nd}$ isotopic data on clinopyroxene separates from representative suites enabled us to establish some significant points:

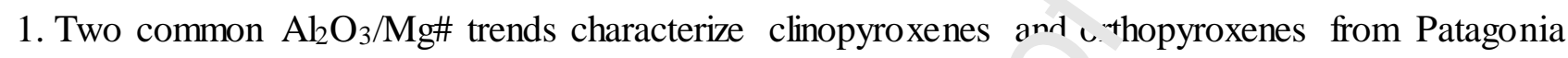
mantle xenoliths, and a systematic distribution can be identified it - inopyroxenes and orthopyroxenes in harzburgites/lherzolites are isolated from those belong o $_{1} \cdot$ to wehrlites, websterites, dunites, orthopyroxenites, and clinopyroxenites. Northern Patargor? clinopyroxenes lie on a well-defined high $\mathrm{Al}_{2} \mathrm{O}_{3} / \mathrm{Mg} \#$ trend; the distribution of those fre $n$-entral Patagonia xenoliths is scattered and follows both a high $\mathrm{Al}_{2} \mathrm{O}_{3} / \mathrm{Mg} \#$ and a low $\mathrm{A}_{2}^{1} \mathrm{O}_{3} / \mathrm{Mg} \#$ trend; a narrower compositional spectrum typified Southern Patagonia clinopyroxene.

2. Trace element content of clinopyrover. suggests that the SCLM beneath Patagonia is extremely heterogeneous. At Cerro Rio $\mathrm{Ch}$ i un and Gobernador Gregores, the positive correlations between $(\mathrm{La} / \mathrm{Yb})_{\mathrm{N}}$ and $\mathrm{Sr}_{\mathrm{N}}$ and $\mathrm{Al}_{2} \mathrm{O}_{3}$, tog the $\mathrm{r}$ with the modal occurrence of amphibole and phlogopite, favour the involvement of long-m thug enrichment processes, or, alternatively, of high melt(fluid)/rock ratios, capable of restoring fertile conditions in the mantle (refertilisation). The negative correlations between $(\mathrm{La} / \mathrm{Yb})_{\mathrm{N}}$ and $\mathrm{Sr}_{\mathrm{N}}$ and $\mathrm{Al}_{2} \mathrm{O}_{3}$ and/or the absence of a well-defined trend in most Patagonian localities are consistent with a variable action of enriched fluids/melts pervading the SCLM. Such processes, which occurred in a relatively limited timespan or were characterized by lower melt(fluid)/rock ratios, can be defined as metasomatism. A few portions of the mantle are instead devoid of significant metasomatic features, as suggested by Ntaflos et al. (2007).

3. The partial melting degree recorded by clinopyroxenes and orthopyroxenes in Patagonian harzburgites and lherzolites ranges from $1 \%$ to $30 \%$. Results from partial melting models show that 
a progressively decreasing partial melting degree is recorded moving from Northern to Southern Patagonia. Consistently, forsterite content of olivine decreases from Northern to Southern Patagonia samples. The calculated $F$ values for Northern Patagonia xenoliths are also consistent with the partial melting degrees proposed in the literature to explain the generation of the Somoncura lavas (Kay et al., 2007). Coupled with the Re-Os age data recently proposed by Mundl et al. $(2015,2016)$ and Schilling et al. (2008, 2017), these features suggest that the SCLM domains beneath Southern Patagonia experienced lower melt extractions in older times with respect to the Northern ones.

4. The overlap between the Sr-Nd isotopic signature of Northern C $n$ tral, and Southern Patagonia clinopyroxenes is ascribable to the "obliterating" action of rt ent enrichment processes, as also testified by the overlap in the distribution of the plateau lavas 'Gorring et al., 2003; Kay et al., 2013). Some mantle xenoliths align quite well along the mixing cuve between DMM and EM II, even if the scattered data distribution makes it difficult 0 tis riminate between the EM I and EM II contributions. Irrespective of the geograph $\mathrm{a}^{1}$ provenance, extraction age, and distance between sampling localities of the xenoliths and $\mathrm{u}^{2}$ trench, clinopyroxenes from websterites and wehrlites plot along the mixing trend between $~ C M_{M}$ and EM II component. Altogether, these data suggest that both the addition of sediments flukis during subduction-related processes and the occurrence of OIB-like pulses during Cenozon $\mathrm{r}$ ateau magmatism could have overprinted the $\mathrm{Sr}-\mathrm{Nd}$ signature of Patagonian mantle xenolitı

5. Northern Patagonia SCLM was infiltrated by tholeiitic melts that modified the major/trace element composition of clinopyroxene in harzburgites/lherzolites and generated high $\mathrm{Al}_{2} \mathrm{O}_{3} / \mathrm{Mg \#}$ and LREEdepleted patterns of clinopyroxene in websterites. Evidence of the existence of tholeiitic enrichment is provided by the REE-depleted patterns of clinopyroxene inside harzburgites/lherzolites from some localities (Estancia Alvarez, Cerro Chenque, Puesto Diaz, Paso de los Indios). The presence of a poorly efficient alkaline enrichment process is instead recorded by some LREE-enriched high Mg\# clinopyroxenes in harzburgites/lherzolites (Cerro Mojon, Comallo, Prahuaniyeu, Cerro Rio Chubut, and Cerro de los Chenques), as well as by websteritic xenoliths with low $\mathrm{Al}_{2} \mathrm{O}_{3} / \mathrm{Mg} \#$ and LREE- 
enriched clinopyroxenes. In Central Patagonia, both a tholeiitic and an alkaline enrichment process modified the major/trace element composition of clinopyroxene in lherzolites/harzburgites and generated websteritic and wehrlitic domains. The interaction with a tholeiitic melt is demonstrated at Cerro Clark, where both websterites and harzburgites/lherzolites with LREE-depleted clinopyroxenes were documented. However, the percolation of an alkaline agent is hypothesized for Estancia Sol de Mayo and Gobernador Gregores, where wehrlites and harzburgites/lherzolites with LREE-enriched clinopyroxenes were found. The "intermediate" behaviour of some clinopyroxenes in websterites and wehrlites (high $\mathrm{Al}_{2} \mathrm{O}_{3} / \mathrm{Mg \#}$ but LREE-enriched patterns) are concisu nt with the involvement of a melt with transitional affinity beneath Estancia Sol de M ^yc and Gobernador Gregores. Melt extraction is the main process recorded by Southern Patagn $\eta_{\text {I. }}{ }^{n}$ xenoliths (Ntaflos et al., 2007), even if the geochemical features of some clinopyroxeres from Pali Aike and Cerro Fraile harzburgites/lherzolites lead to speculation that t'e $\rightarrow+$ wo SCLM domains interacted with alkaline and $\mathrm{SiO}_{2}$-saturated proto-adakitic agents, $\mathrm{r}_{\mathrm{r}}$ pe -tively (Dantas, 2007; Faccini et al., 2013; Mundl et al., 2015).

6. The occurrence of both tholeiitic and aline enrichments in the Patagonia SCLM is consistent with the evolutionary sequence dc cribud by D'Orazio et al. (2004), Gorring et al. (2003) and Kay et al. (2007; 2013) for Patagoniaı rlateau magmatism, where limited alkaline pulses followed the emission of large volumes m inoleiitic lavas. In this framework, it is likely to imagine that a first tholeiitic enrichment process beneath Northern-Central Patagonia SCLM was followed by the percolation of transitional-alkaline agents, even if the infiltration of subduction-derived melts/fluids into the mantle wedge cannot be excluded and is still debated (Gorring et al., 2003; Kay et al., 2013). 7. A systematic Sr-Nd discrimination between clinopyroxenes in refertilised mantle suites (Cerro Rio Chubut and Gobernador Gregores) and those belonging to metasomatized ones can be done. The general $\mathrm{Sr}$ isotopic depletion of the formers highlights that the refertilisation processes in the Patagonian SCLM were caused by long-lasting reactions between the depleted mantle and the transitional-alkaline enrichment agents. 


\section{Acknowledgements}

This work is part of a co-tutorship Ph.D. held within the 2008 Vinci Project "Matter transfer in suprasubductive mantle in complex converging systems". The project was funded by the Italian National Research Program [PRIN_2017 Project 20178LPCPW] to [MC], and by the "Università Italo-Francese". The activities were conducted between the University of Ferrara and the Observatoire Midi-Pyrenees in Toulouse. MM appreciates the support of the project ALPIMED (PIECSIC-201530E082). We thank the laboratory staff of the UMR 5: 3 (GET, Observatoire MidiPyrenees) of the University Paul Sabatier (Toulouse III) for t $t^{2}$ ell support during the performance of TIMS analyses.

\section{References}

Aliani, P., Ntaflos, T., Bjerg, E., 2009. O. oin of melt pockets in mantle xenoliths from southern Patagonia, Argentina. Journal of Sı'th American Earth Sciences 28, 419-428.

Arai, S., Shimizu, Y., Morishita, T., Ishic a Y., 2006. A new type of orthopyroxenite xenolith from Takashima, Southwest $\mathrm{J}_{i} \cdot$ an: silica enrichment of the mantle by evolved alkali basalt. Contributions to Mineran ov and Petrology 152(3), 387.

Ardolino, A., Franchi, M., 'eıırsal, M., Salani, F., 1999. El volcanismo en la Patagonia Extraandina. Geología Argentina 29, 579-612.

Benoit, M., Ceuleneer, G., Polvé, M., 1999. The remelting of hydrothermally altered peridotite at mid-ocean ridges by intruding mantle diapirs. Nature 402, 514-518.

Bjerg, E.A., Ntaflos, T., Kurat, G., Dobosi, G., Labudía, C.H., 2005. The upper mantle beneath Patagonia, Argentina, documented by xenoliths from alkali basalts. Journal of South American Earth Sciences 18, 125-145. 
Bjerg, E.A., Ntaflos, T., Thöni, M., Aliani, P., Labudia, C.H., 2009. Heterogeneous lithospheric mantle beneath Northern Patagonia: Evidence from Prahuaniyeu garnet- and spinelperidotites. Journal of Petrology 50, 1267-1298.

Bonadiman, C., Coltorti, M., 2011. Numerical modelling for peridotite phase melting trends in the $\mathrm{SiO}_{2}-\mathrm{Al}_{2} \mathrm{O}_{3}-\mathrm{FeO}-\mathrm{MgO}-\mathrm{CaO}$ system at $2 \mathrm{GPa}$. Mineralogical Magazine 75, 548-548.

Cande, S.C., Leslie, R.B., 1986. Late Cenozoic tectonics of the southern Chile Trench. Journal of Geophysical Research 91, 471-496.

Conceição, R.V., Mallmann, G., Koester, E., Schilling, M., Bertntto, G.W., Rodriguez-Vargas, A., 2005. Andean subduction-related mantle xenoliths: I vu Jic evidence of $\mathrm{Sr}-\mathrm{Nd}$ decoupling during metasomatism. Lithos 82, 273-287.

Corbella, H., Chelotti, L., Pomposiello, C., 1996. Neoterto. 'ca del rift Jurasico austral en Pali Aike, Patagonia Extrandina, Santa Cruz, Arge th + XIII Congreso Geologico Argentino y III Congreso de Exploracion de Hidroc a'br os, Actas 2, 383-393.

Dantas, C., 2007. Caractérisation du manı эu supérieur Patagonien: Les enclaves ultramafiques et mafiques dans les laves alcalin`s. Uuliversité de Toulouse III p. 323.

Dantas, C., Grégoire, M., Koester, E., Conceição, R.V., Rieck Jr, N., 2009. The Therzolite-websterite xenolith suite from Ncth rn Patagonia (Argentina): Evidence of mantle-melt reaction processes. Lithos $1 \imath^{\urcorner 7}$, iv7-120.

DePaolo, D.J., Wasserburg, G.J., 1979. Petrogenetic mixing models and Nd-Sr isotopic patterns. Geochimica et Cosmochimica Acta 43, 615-627.

Diraison, M., Cobbold, P.R., Gapais, D., Rossello, E.A., 1997. Magellan Strait: Part of a Neogene rift system. Geology 25, 703-706.

D'Orazio, M., Agostini, S., Mazzarini, F., Innocenti, F., Manetti, P., Haller, M.J., Lahsen, A., 2000. The Pali Aike Volcanic Field, Patagonia: Slab-window magmatism near the tip of South America. Tectonophysics 321, 407-427. 
D'Orazio, M., Innocenti, F., Manetti, P., Haller, M. J., 2004. The Cenozoic back-arc magmatism of the southern extra-Andean Patagonia $\left(44.5-52^{\circ} \mathrm{S}\right)$ : A review of geochemical data and geodynamic interpretations. Revista de la Asociación Geológica Argentina 59(4), 525-538

Faccini, B., Bonadiman, C., Coltorti, M., Grégoire, M., Siena, F., 2013. Oceanic material recycled within the sub-patagonian lithospheric mantle (Cerro del Fraile, Argentina). Journal of Petrology 54, 1211-1258.

Faure, G., 1986. Principles of isotope geology. John Wiley and Sons, Inc.,New York, NY; None.

Folguera, A., Encinas, A., Echaurren, A., Gianni, G., Orts, D., Valı `cia, V., Carrasco, G., 2018. Constraints on the Neogene growth of the central Patag snim $\eta$ Andes at the latitude of the Chile triple junction $\left(45-47^{\circ} \mathrm{S}\right)$ using $\mathrm{U} / \mathrm{Pb}$ geochronolno $\sigma_{\mathrm{V}}$ in synorogenic strata. Tectonophysic $\mathrm{s}$ $744,134-154$.

Gorring, M.L., Kay, S.M., 2000. Carbonatite re. so natized peridotite xenoliths from southern Patagonia: Implications for lithos, he ic processes and Neogene plateau magmatism. Contributions to Mineralogy and rtrology 140, 55-72.

Gorring, M.L., Kay, S.M., Zeitler, P K., F.amos, V.A., Rubiolo, D., Fernandez, M.I., Panza, J.L., 1997. Neogene Patagonian latedu lavas: Continental magmas associated with ridge collision at the Chile Triple Juncth n Tectonics 16, 1-17.

Gorring, M.L., Singer, B., Towers, J., Kay, S.M., 2003. Plio-Pleistocene basalts from the Meseta del Lago Buenos Aires, Argentina: Evidence for asthenosphere-lithosphere interactions during slab window magmatism. Chemical Geology 193, 215-235.

Hart, S.R., 1988. Heterogeneous mantle domains: signatures, genesis and mixing chronologies. Earth and Planetary Science Letters 90(3), 273-296.

Kay, S.M., Ardolino, A.A., Gorring, M.L., Ramos, V.A., 2007. The Somuncura large igneous province in Patagonia: Interaction of a transient mantle thermal anomaly with a subducting slab. Journal of Petrology 48, 43-77. 
Kay, S.M., Gorring, M., Ramos, V.A., 2004. Magmatic sources, setting and causes of Eocene to recent Patagonian plateau magmatism $\left(36^{\circ} \mathrm{S}\right.$ to $52^{\circ} \mathrm{S}$ latitude). Revista de la Asociacion Geologica Argentina 59, 556-568.

Kay, S.M., Jones, H.A., Kay, R.W., 2013. Origin of Tertiary to Recent EM-and subduction-like chemical and isotopic signatures in Auca Mahuida region (37-38 S) and other Patagonian plateau lavas. Contributions to Mineralogy and Petrology 166(1), 165-192.

Kay, S.M., Ramos, V.A., Mpodozis, C., Sruoga, P., 1989. Late Paleozoic to Jurassic silicic magmatism at the Gondwana margin: analogy to the Middle P"oterozoic in North America? Geology 17, 324-328.

Kilian, R., Stern, C.R., 2002. Constraints on the interaction bu ween slab melts and the mantle wedge from adakitic glass in peridotite xenoliths. Europsaı Journal of Mineralogy 14, 25-36.

Laurora, A., Mazzucchelli, M., Rivalenti, G., Va $\varkappa_{.}$s;, R., Zanetti, A., Barbieri, M.A., Cingolani, C.A., 2001. Metasomatism and me'.ng in carbonated peridotite xenoliths from the mantle wedge: The Gobernador Gregores ı 'se (Southern Patagonia). Journal of Petrology 42, 69-87. Le Roux, V., Bodinier, J.L., Tommari \ Alard, O., Dautria, J.M., Vauchez, A., Riches, A.J.V., 2007. The Lherz spinel lhe. "olite. Refertilized rather than pristine mantle. Earth and Planetary Science Letters 259, 593 612 .

MacGregor, I.D., 1974. '1 's system MgO-A2O3-SiO2: Solubility of ARO3 in enstatite for spinel and garnet peridotite compositions. Am. Mineral. 59, 110-119.

McDonough, W.F., Sun, S.S., 1995. The composition of the Earth. Chemical Geology 120, 223-253. Melchiorre, M., Coltorti, M., Gregoire, M., Benoit, M., 2015. Refertilization process in the Patagonian subcontinental lithospheric mantle of Estancia Sol de Mayo (Argentina). Tectonophysics 650, 124-143.

Mercier, J.C.C., Nicolas, A., 1975. Textures and fabrics of upper-mantle peridotites as illustrated by xenoliths from basalts. Journal of Petrology 16, 454-487. 
Mundl, A., Ntaflos, T., Ackerman, L., Bizimis, M., Bjerg, E.A., Hauzenberger, C.A., 2015. Mesoproterozoic and Paleoproterozoic subcontinental lithospheric mantle domains beneath southern Patagonia: Isotopic evidence for its connection to Africa and Antarctica. Geology 43(1), 39-42.

Mundl, A., Ntaflos, T., Ackerman, L., Bizimis, M., Bjerg, E.A., Wegner, W., Hauzenberger, C.A., 2016. Geochemical and Os-Hf-Nd-Sr Isotopic Characterization of North Patagonian Mantle Xenoliths: Implications for Extensive Melt Extraction and Percolation Processes. Journal of Petrology 57(4), 685-715.

Ntaflos, T., Bjerg, E.A., Labudia, C.H., Kurat, G., 2007. Deple.eu linosphere from the mantle wedge beneath Tres Lagos, southern Patagonia, Argentina Lthos 94, 46-65.

O’Reilly, S.Y., Griffin W.L., 2013. Mantle Metasomatisı. In: Metasomatism and the Chemical Transformation of Rock. Lecture Notes in Earth System Sciences. Springer, Berlin, Heidelberg.

Pankhurst, R.J., Rapela, C.R., 1995. Produ tion of Jurassic rhyolite by anatexis of the lower crust of Patagonia. Earth and Planetary Science Letters 134, 23-36.

Pelorosso, B., Bonadiman, C., Ce tort, M., Faccini, B., Melchiorre, M., Ntaflos, T., Gregoire, M., 2016. Pervasive, thole1. ${ }^{\text {ic }}$ refertilisation and heterogeneous metasomatism in Northern Victoria Land lithos, ${ }_{1}$ heıı mantle (Antarctica). Lithos 248-251, 493-505.

Ramos, V.A., Kay, S.M., 1992. Southern Patagonian plateau basalts and deformation: Backarc testimony of ridge collisions. Tectonophysics 205, 261-282.

Ramos, V.A., Riccardi, A.C., Rolleri, E.O., 2004. Límites naturales del norte de la Patagonia. Revista de la Asociación Geológica Argentina 59(4), 785-786.

Rapela, C.W., Kay, S.M., 1988. Late Paleozoic to recent magmatic evolution of northern Patagonia. Episodes 11, 175-182. 
Rapela, C.W., Spalletti, L.A., Merodio, J.C., Aragón, E., 1988. Temporal evolution and spatial variation of early tertiary volcanism in the Patagonian Andes $\left(40^{\circ} \mathrm{S}-42^{\circ} 30^{\prime} \mathrm{S}\right)$. Journal of South American Earth Sciences 1, 75-88.

Rivalenti, G., Mazzucchelli, M., Laurora, A., Ciuffi, S.I.A., Zanetti, A., Vannucci, R., Cingolani, C.A., 2004. The backarc mantle lithosphere in Patagonia, South America. Journal of South American Earth Sciences 17, 121-152.

Rivalenti, G., Mazzucchelli, M., Zanetti, A., Vannucci, R., Bollinger, C., Hémond, C., Bertotto, G.W., 2007. Xenoliths from Cerro de los Chenques (Patagonia): An example of slab-related metasomatism in the backarc lithospheric mantle. Lithr, $x, y, 45-67$.

Schilling, M.E., Carlson, R.W., Conceição, R.V., Dantas, C.., Bertotto, G.W., Koester, E., 2008. ReOs isotope constraints on subcontinental lithosrhe. ${ }^{c}$ mantle evolution of southern South America. Earth and Planetary Science Lett 21 . 2 ,8(1-2), 89-101.

Schilling, M.E., Carlson, R.W., Tassara, ‘ , ¿onceição, R.V., Bertotto, G.W., Vásquez, M., ..., Morata, D., 2017. The origin of Pan ronia revealed by Re-Os systematics of mantle xenoliths. Precambrian Research 294, 15.32

Schilling, M.E., Conceição, R.V., Maınann, G., Koester, E., Kawashita, K., Hervé, F., ..., Motoki, A., 2005. Spinel-facies $r$ antle xenoliths from Cerro Redondo, Argentine Patagonia: Petrographic, geocı 'nucal, and isotopic evidence of interaction between xenoliths and host basalt. Lithos 82(3-4), 485-502.

Scott, J. M., Liu, J., Pearson, D.G., Waight, T.E., 2016. Mantle depletion and metasomatism recorded in orthopyroxene in highly depleted peridotites. Chemical Geology 441, 280-291.

Snow, J.E., Hart, S.R., Dick, H.J.B., 1994. Nd and Sr isotope evidence linking mid-ocean-ridge basalts and abyssal peridotites. Nature 371, 57-60.

Stern, C.R., Kilian, R., 1996. Role of the subducted slab, mantle wedge and continental crust in the generation of adakites from the Andean Austral Volcanic Zone. Contributions to Mineralogy and Petrology 123, 263-281. 
Stern, C.R., Kilian, R., Olker, B., Hauri, E.H., Kyser, T.K., 1999. Evidence from mantle xenoliths for relatively thin $(<100 \mathrm{~km})$ continental lithosphere below the Phanerozoic crust of southernmost South America. In Developments in Geotectonics. Elsevier, vol. 24, pp. 217235.

Stern, C.R., Saul, S., Skewes, M.A., Futa, K., 1989. Garnet peridotite xenoliths from the Pali-Aike alkali basalts of southernmost South America. Kimberlites and Related Rocks 14, 735-744.

Sun, S.S., McDonough, W.F., 1989. Chemical and isotopic systematics of oceanic basalts: implications for mantle composition and processes. Magmatis n. in the ocean basins, 313-345.

Thomson, S.N., Brandon, M.T., Tomkin, J.H., Reiners, P.`v., Vasquez, C., Wilson, N.J., 2010. Glaciation as a destructive and constructive contrnl un mountain building. Nature 467, 313317.

Upton, B.G.J., Downes, H., Kirstein, L.A., Bc ıa im ın, C., Hill, P.G., Ntaflos, T., 2011. The lithospheric mantle and lower cru ${ }^{-t}$ rantle relationships under Scotland: A xenolithic perspective. Journal of the Geologi.1 Society 168, 873-886.

Walter, M.J., 2003. Melt extraction and (n npositional variability in mantle lithosphere. The Mantle \& Core. Treatise of Geoch mistı y 2, 363-394.

Workman, R.K., Hart, S.R., ¿`ר Major and trace element composition of the depleted MORB mantle (DMM). Eàth and Planetary Science Letters 231, 53-72.

Zindler, A., Hart, S., 1986. Chemical geodynamics. Annual review of Earth and planetary sciences. Vol. 14, 493-571.

Zou, H., 1998. Trace element fractionation during modal and nonmodal dynamic melting and opensystem melting: a mathematical treatment. Geochimica et Cosmochimica Acta 62, 1937-1945.

\section{Figure captions}

Fig. 1 (colour online) 
Topographic and tectonic map of Patagonia showing the distribution of the Eocene to present days back arc plateau lavas and the known mantle xenoliths-bearing localities (modified after Kay et al, 2007; Thomson et al., 2010). Dashed lines identify Northern (39/40-46 $\mathrm{S})$, Central (46-49 $\mathrm{S})$ and Southern Patagonia (49-52 ${ }^{\circ}$ S). Northern Patagonia: 1 = Laguna Fria; 2 = Cerro Chenque; 3 = Puesto Diaz; 4 = Estancia Alvarez; $5=$ Cerro Aznares; $6=$ Comallo; $7=$ Cerro Mojon; $8=$ Prahuaniyeu; $9=$ Traful; 10 = Cerro Rio Chubut; $11=$ Paso de los Indios; $12=$ Cerro de los Chenques; $13=$ Coyhaique . Central Patagonia: $14=$ Chile Chico; $15=$ Cerro Clark; $16=$ Estancia Sol de Mayo; $17=$ Don Camilo; $18=$ Cerro Cuadrado; $19=$ Auvernia; $20=$ Gobernador Gregores $(+.7$ stancia Lote 17); $21=$ Cerro Redondo. Southern Patagonia: $22=$ Tres Lagos; $23=$ Cerro Fr. ^llc, $\angle 4=$ Las Cumbres; $25=$ Pali Aike (data from Aliani et al., 2009; Bjerg et al., 2005, 2009; Concicao et al., 2005; Dantas, 2007; Dantas

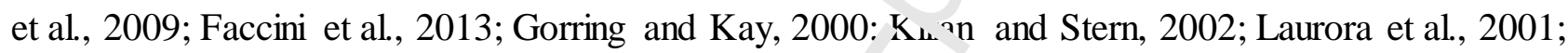
Melchiorre et al., 2015; Mundl et al., 2015, 2016; taf $^{f}$ os et al., 2007; Rivalenti et al., 2004, 2007; Schilling et al., 2005, 2008, 2017; Stern et a'. 1 ' 999).

\section{Fig. 2 (colour online)}

$\mathrm{Al}_{2} \mathrm{O}_{3}$ (wt\%) vs. Mg\# diagrams cowng the distribution of clinopyroxenes in Patagonian mantle xenoliths (from Aliani et al., 父99, Bjerg et al., 2005, 2009; Conceicao et al,, 2005; Dantas, 2007; Dantas et al., 2009; Faccin. eı al., 2013; Gorring and Kay, 2000; Kilian and Stern, 2002; Laurora et al., 2001; Melchiorre et al., 2015; Mundl et al., 2015, 2016; Ntaflos et al., 2007; Rivalenti et al., 2004, 2007; Schilling et al., 2005, 2008, 2017; Stern et al., 1999). In the upper panels is reported the composition of clinopyroxene in harzburgites and lherzolites from (a) Northern, (b) Central, and (c) Southern Patagonia. In the lower panels is reported the composition of clinopyroxene in dunites, wehrlites, websterites, orthopyroxenites and clinopyroxenites from (d) Northern, (e) Central, and (f) Southern Patagonia.

\section{Fig. 3 (colour online)}


$\mathrm{Al}_{2} \mathrm{O}_{3}$ (wt $\%$ ) vs. Mg\# diagrams showing the distribution of orthopyroxenes in Patagonian mantle xenoliths (from Aliani et al., 2009; Bjerg et al., 2005, 2009; Conceicao et al., 2005; Dantas, 2007; Dantas et al., 2009; Faccini et al., 2013; Gorring and Kay, 2000; Kilian and Stern, 2002; Laurora et al., 2001; Melchiorre et al., 2015; Mundl et al., 2015, 2016; Ntaflos et al., 2007; Rivalenti et al., 2004, 2007; Schilling et al., 2005, 2008, 2017; Stern et al., 1999). In the upper panels the composition of orthopyroxene in harzburgites and lherzolites from (a) Northern, (b) Central, and (c) Southern Patagonia is reported. In the lower panels the composition of orthopyroxene in dunites, wehrlites, websterites, orthopyroxenites, and clinopyroxenites from (d) Norther ${ }_{1,}$ (e) Central, and (f) Southern Patagonia is reported.

\section{Fig. 4 (colour online)}

$\mathrm{NiO}$ (wt\%) vs. Fo diagrams showing the comr os: 10. of olivine in harzburgitic and lherzolitic (circles) and in dunitic, wehrlitic, webste +ic and orthopyroxenitic (crosses) xenoliths from (a) Northern, (b) Central, and (c) Southern Pà ’gonia. Data from Aliani et al. (2009), Bjerg et al. (2005, 2009), Conceicao et al. (2005),; Dantas T'J07), Dantas et al. (2009), Faccini et al. (2013), Gorring and Kay (2000), Kilian and Stern ?00 L), Laurora et al. (2001), Melchiorre et al. (2015), Mundl et al. (2015, 2016), Ntaflos et al. (2(心7) Rivalenti et al. (2004, 2007), Schilling et al. (2005, 2008, 2017), and Stern et al. (1999).

\section{Fig. 5 (colour online)}

Chondrite-normalized (Sun and McDonough, 1989) La/Yb (a, b, c) and $\mathrm{Sr}(\mathrm{d}, \mathrm{e}, \mathrm{f})$ vs. $\mathrm{Al}_{2} \mathrm{O}_{3}$ (wt\%) diagrams showing the behavior of clinopyroxenes from Northern, Central, and Southern Patagonia mantle xenoliths. (a) Clinopyroxenes characterized by negative correlation between $(\mathrm{La} / \mathrm{Yb})_{\mathrm{N}}$ and $\mathrm{Al}_{2} \mathrm{O}_{3}$ (wt\%); (b) clinopyroxenes with positive correlation between $(\mathrm{La} / \mathrm{Yb})_{\mathrm{N}}$ and $\mathrm{Al}_{2} \mathrm{O}_{3}$ (wt\%); (c) clinopyroxenes without any clear correlation between $(\mathrm{La} / \mathrm{Yb})_{\mathrm{N}}$ and $\mathrm{Al}_{2} \mathrm{O}_{3}$ (wt \%); (d) clinopyro xe ne showing a negative correlation between $\mathrm{Sr}_{\mathrm{N}}$ and $\mathrm{Al}_{2} \mathrm{O}_{3}$ (wt\%); (e) clinopyroxenes with positive 
correlation between $\mathrm{Sr}_{\mathrm{N}}$ and $\mathrm{Al}_{2} \mathrm{O}_{3}$ (wt\%); (f) clinopyroxenes without any clear correlation between $\mathrm{Sr}_{\mathrm{N}}$ and $\mathrm{Al}_{2} \mathrm{O}_{3}$ (wt\%). Data from Aliani et al. (2009), Bjerg et al. (2005, 2009), Conceicao et al. (2005), Dantas (2007), Dantas et al. (2009), Faccini et al. (2013), Gorring and Kay (2000), Kilian and Stern (2002), Laurora et al. (2001), Melchiorre et al. (2015), Mundl et al. (2015, 2016), Ntaflos et al. (2007), Rivalenti et al. (2004, 2007), Schilling et al. (2005, 2008, 2017), and Stern et al. (1999).

\section{Fig. 6 (colour online)}

${ }^{143} \mathrm{Nd} /{ }^{144} \mathrm{Nd}$ vs. ${ }^{87} \mathrm{Sr} /{ }^{86} \mathrm{Sr}$ diagram showing the isotopic signature or linopyroxene separates from Cerro Rio Chubut, Cerro de los Chenques, Cerro Clark, Estanc a ¿̃ol de Mayo, Gobernador Gregores, Cerro Fraile, and Pali Aike mantle xenoliths. Literatıı data showing the composition of clinopyroxene separates from Northern, Central, and S, 'thern Patagonia mantle xenoliths are reported in the fields defined by the dotted, dashrd $10^{+}$.ed and solid lines, respectively (see text for references). Depleted (DMM) and enriched ( $\mathrm{E}^{\top} \mathrm{i}$ I; EM II) mantle end-members are from Workman and Hart (2005), Zindler and Hart (1980, and Hart (1988). Mantle array is plotted according to DePaolo and Wasserburg (1979); BCE - Bulk Silicate Earth $\left({ }^{87} \mathrm{Sr} /{ }^{86} \mathrm{Sr}=0.70445 ;{ }^{143} \mathrm{Nd} /{ }^{144} \mathrm{Nd}=\right.$ 0.51264; Faure, 1986).

\section{Fig. 7 (colour online)}

$\mathrm{Al}_{2} \mathrm{O}_{3}$ (wt $\%$ ) vs. $\mathrm{MgO}$ (wt\%) diagrams showing the composition of orthopyroxenes from (a) Northern, (b) Central, and (c) Southern Patagonia harzburgites and lherzolites (from Aliani et al., 2009; Bjerg et al., 2005, 2009; Conceicao et al., 2005; Dantas, 2007; Dantas et al., 2009; Faccini et al., 2013; Gorring and Kay, 2000; Kilian and Stern, 2002; Laurora et al., 2001; Melchiorre et al, 2015; Mundl et al., 2015, 2016; Ntaflos et al., 2007; Rivalenti et al., 2004, 2007; Schilling et al., 2005, 2008, 2017; Stern et al., 1999). Curves in (a), (b), and (c) are referred to the melting model of Upton et al. (2011), developed from a starting Primitive Mantle (PM) composition (McDonough and Sun, 1995). Numbers along the curves correspond to the partial melting percentages. Since Upton et al. 
(2011) model works only in the spinel stability field, for Prahuaniyeu and Pali Aike localities - where both spinel- and garnet-bearing peridotites are documented - only data from spinel-bearing peridotites were plotted.

\section{Fig. 8 (colour online)}

$\mathrm{Al}_{2} \mathrm{O}_{3}$ (wt\%) vs. $\mathrm{MgO}$ (wt\%) diagrams showing the composition of clinopyroxenes from (a) Northern, (b) Central, and (c) Southern Patagonia harzburgites and lherzolites (from Aliani et al., 2009; Bjerg et al., 2005, 2009; Conceicao et al., 2005; Dantas, 2007; Dantas et ‘', 2009; Faccini et al., 2013; Gorring and Kay, 2000; Kilian and Stern, 2002; Laurora et al, $L^{\top}(01$; Melchiorre et al., 2015; Mundl et al., 2015, 2016; Ntaflos et al., 2007; Rivalenti et al., 2004. 2707; Schilling et al., 2005, 2008, 2017; Stern et al., 1999). Curves in (a), (b), and (c) are referred to the melting model of Upton et al. (2011), developed from a starting Primitive Mantle (PN. r smposition (McDonough and Sun, 1995). Numbers along the curves correspond to th - $p$ rtial melting percentages. Since Upton et al. (2011) model works only in the spinel stability $\mathrm{hc}^{\mathrm{I}} \mathrm{\gamma}$, for Prahuaniyeu and Pali Aike localities - where both spinel- and garnet-bearing peridotites as s locumented - only data from spinel-bearing peridotites were plotted.

\section{Fig. 9 (colour online)}

Primitive mantle- (PM) normalized $\mathrm{Yb}$ vs. Y diagrams showing the composition of clinopyroxenes from (a) Northern, (b) Central, and (c) Southern Patagonia harzburgites and lherzolites (from Aliani et al., 2009; Bjerg et al., 2005, 2009; Conceicao et al., 2005; Dantas, 2007; Dantas et al., 2009; Faccini et al, 2013; Gorring and Kay, 2000; Kilian and Stern, 2002; Laurora et al., 2001; Melchiorre et al., 2015; Mundl etal., 2015, 2016; Ntaflos et al., 2007; Rivalenti et al., 2004, 2007; Schilling et al., 2005, 2008, 2017; Stern et al., 1999). Curves in (a), (b), and (c) are referred to the melting model of Zou (1998), developed from a starting Primitive Mantle (PM) composition (McDonough and Sun, 1995). Numbers along the curves correspond to the partial melting percentages. Since Zou (1998) model 
works only in the spinel stability field, for Prahuaniyeu and Pali Aike localities - where both spineland garnet-bearing peridotites are documented - only data from spinel-bearing peridotites were plotted.

\section{Fig. 10 (colour online)}

${ }^{143} \mathrm{Nd} /{ }^{144} \mathrm{Nd} v{ }^{87} \mathrm{Sr} /{ }^{86} \mathrm{Sr}$ isotopic signature of clinopyroxenes from Patagonia mantle xenoliths plotted onto the mixing curves between depleted (DMM) and enriched (EM I-EM II) mantle reservoirs. (a) Geographical subdivision of the samples (Northern vs. Central 's. Southern Patagonia). (b) Lithological subdivision of the samples (lherzolites/harzbr gi as vs. websterites/wehrlites). (c) Subdivision of the samples based on the correlation between -ace elements $(\mathrm{La} / \mathrm{Yb} ; \mathrm{Sr})$ and $\mathrm{Al}_{2} \mathrm{O}_{3}$ of clinopyroxene (i.e. negative vs. positive; see text for further explanation). The three curves plotted in (a), (b), and (c) represent the mixing models be wi n DMM and EM I-EM II end-members. The mixing model between DMM and EM I ( $>$ m, onents is developed in accordance with Kay et al. (2013). The two mixing models between LMM and EM II were obtained by varying the Sr content of the EM II reservoir from 750 to 140 n,m, thus changing its $\mathrm{Sr} / \mathrm{Nd}$ ratio from 13.8 to 2.6. The percentages of EM I-EM II con.' 'onents in each of the mixing models are also reported on the corresponding curves. Depletea (T.MM) and enriched (EM I; EM II) mantle end-members are from Workman and Hart (2005), "suuler and Hart (1986), and Hart (1988).

\section{Fig. 11 (colour online)}

Average partial melting degrees $(\mathrm{F} \%)$ calculated for orthopyroxenes and clinopyroxenes, forsterite content of olivines, $\mathrm{T}_{\mathrm{RD}}$ (Re-Os) age recorded by mantle xenoliths and ages of the xenoliths-bearing lavas from each Patagonian locality plotted against latitude $\left({ }^{\circ} \mathrm{S}\right)$. (a) Averaged partial melting degrees recorded by orthopyroxenes major element composition $\left(\mathrm{Al}_{2} \mathrm{O}_{3}\right.$ vs $\left.\mathrm{MgO}\right)$. (b) Averaged partial melting degrees recorded by clinopyroxenes major element composition $\left(\mathrm{Al}_{2} \mathrm{O}_{3}\right.$ vs $\left.\mathrm{MgO}\right)$. (c) Averaged partial melting degrees recorded by clinopyroxenes trace element composition ( $\mathrm{Y}_{\mathrm{N}}$ vs 
$\mathrm{Yb}_{\mathrm{N}}$ ). (d) Averaged Fo content of olivines in therzolites and harzburgites. (e) Averaged Rhenium depletion ages ( $\mathrm{T}_{\mathrm{RD}} ; \mathrm{Ga}$ ) yielded by Patagonia xenoliths. (f) Age span of the xenoliths-bearing Patagonia lavas (Ma). Dotted lines indicate the subdivision between Northern $\left(39 / 40-46^{\circ} \mathrm{S}\right)$, Central $\left(46-49^{\circ} \mathrm{S}\right)$ and Southern (49-54 S) Patagonia. See text and Table 2 for further explanation and references. Source data from Aliani et al. (2009), Bjerg et al. (2005, 2009), Conceicao et al. (2005); Dantas (2007), Dantas et al. (2009), Faccini et al. (2013), Gorring and Kay (2000), Kilian and Stern (2002), Laurora et al. (2001), Melchiorre et al. (2015), Mundl et al. (2015, 2016), Ntaflos et al. (2007), Rivalenti et al. (2004, 2007), Schilling et al. (2005, 2008, 2017), and _tern et al. (1999).

\section{Fig. 12 (colour online)}

Major element distribution and chondrite-normalized (S un and McDonough, 1989) REE patterns of clinopyroxenes from Patagonian websterites, weł $r$ is orthopyroxenites, and clinopyroxenites. (a) $\mathrm{Al}_{2} \mathrm{O}_{3}$ vs $\mathrm{Mg \#}$ diagram showing the $\mathrm{con}^{-1}$, ition of clinopyroxenes from Northern Patagonia websterites, Central Patagonia websterites, wehrlites, and clinopyroxenites and Southern Patagonia orthopyroxenites and clinopyroxeniter $r h$, black arrows indicate the two main trend followed by clinopyroxenes (high $\mathrm{Al}_{2} \mathrm{O}_{3} / \mathrm{Mg \#}$ : nd $\mathrm{wW} \mathrm{Al}_{2} \mathrm{O}_{3} / \mathrm{Mg}$ ), in accordance with the subdivision proposed by Melchiorre et al. (2015). (b) \ho adrite-normalized REE patterns of clinopyroxenes from Northern Patagonia high $\mathrm{Al}_{2} \mathrm{O}_{3} / \mathrm{Mg}^{\prime}$. websterites; field defined by solid line is referred to clinopyroxenes composition in harzburgites and lherzolites from Estancia Alvarez, Cerro Chenque, Puesto Diaz and Paso de los Indios. (c) Chondrite-normalized REE patterns of clinopyroxenes from Northern Patagonia low $\mathrm{Al}_{2} \mathrm{O}_{3} / \mathrm{Mg} \#$ websterites; field defined by dotted line is referred to clinopyroxenes composition in harzburgites and lherzolites from Cerro Mojon, Comallo, Prahuaniyeu, Cerro Rio Chubut, and Cerro de los Chenques. (d) Chondrite-normalized REE patterns of clinopyroxenes from Central Patagonia high $\mathrm{Al}_{2} \mathrm{O}_{3} / \mathrm{Mg} \#$ websterites and clinopyroxenites; field defined by solid line is referred to clinopyroxene composition in harzburgites and lherzolites from Cerro Clark, Don Camilo, and Cerro Cuadrado. (e) Chondrite-normalized REE patterns of clinopyroxenes from Central 
Patagonia high $\mathrm{Al}_{2} \mathrm{O}_{3} / \mathrm{Mg \#}$ websterites (sample from Gobernador Gregores) and wehrlites; field defined by dotted line is referred to clinopyroxenes composition in harzburgites and lherzolites from Estancia Sol de Mayo and Gobernador Gregores (+ Estancia Lote 17). (f) Chondrite-normalized REE patterns of clinopyroxenes from Southern Patagonia orthopyroxenites. (g) Chondrite-normalized REE patterns of clinopyroxene from Southern Patagonia clinopyroxenites. Fields defined by solid line in (f) and (g) are referred to clinopyroxenes composition in harzburgites and lherzolites from Tres Lagos and Las Cumbres; fields defined by dotted line in (f) and (g) are referred to clinopyroxe ne s composition in harzburgites and lherzolites from Cerro Fraile and $\mathbf{P}_{\mathrm{a}_{\mathrm{i}}}$ Aike. Data from Aliani et al. (2009), Bjerg et al. (2005, 2009), Conceicao et al. (2005); Dan' as 'Zu07), Dantas et al. (2009), Faccini et al. (2013), Gorring and Kay (2000), Kilian and Stern (3)u?), Laurora et al. (2001), Melchiorre et al. (2015), Mundl et al. (2015, 2016), Ntaflos et al. (2007), rivalenti et al. (2004, 2007), Schilling et al. (2005, 2008, 2017), and Stern et al. (1999). Sez ¿'so text and Table 2. 
Table 1

$\mathrm{Sr}-\mathrm{Nd}$ isotopic signature of clinopy roxene separates from representative Patagonian mantle xenoliths. The trace element composition ( $\mathrm{p} \mathrm{pm}$ ) of the selected clinopy roxene are from Aliani et al. (2009), Dantas (2007), Dantas et al. (2009), Faccini et al. (2013) and Melchiorre et al. (2015).

\begin{tabular}{|c|c|c|c|c|c|c|c|c|c|c|c|c|c|c|c|c|c|c|c|c|c|c|c|}
\hline Locality & $\begin{array}{c}\text { Samp } \\
\text { le }\end{array}$ & $\begin{array}{l}\mathbf{R} \\
\mathbf{b}\end{array}$ & Sr & $\begin{array}{l}1 / \\
\mathrm{Sr}\end{array}$ & $\begin{array}{l}{ }^{87} \mathbf{R b} \\
/^{86} \mathrm{Sr} \\
\end{array}$ & $\begin{array}{l}{ }^{87} \mathrm{Sr} / \\
{ }^{86} \mathrm{Sr} \\
\end{array}$ & $2 \sigma$ & $\begin{array}{l}\mathbf{S} \\
\mathbf{m} \\
\end{array}$ & $\begin{array}{l}\mathbf{N} \\
\mathbf{d}\end{array}$ & $\begin{array}{c}1 / \\
\text { Nd }\end{array}$ & $\begin{array}{c}{ }^{147} \mathrm{Sm} / \\
{ }^{144} \mathrm{Nd}\end{array}$ & $\begin{array}{l}{ }^{143} \mathrm{Nd} / \\
{ }^{144} \mathrm{Nd}\end{array}$ & $2 \sigma$ & $\begin{array}{l}\mathbf{L} \\
\mathbf{a}\end{array}$ & $\begin{array}{l}\mathrm{C} \\
\mathrm{e}\end{array}$ & $\begin{array}{l}\mathbf{N} \\
\mathbf{d}\end{array}$ & $\begin{array}{l}\mathbf{S} \\
\mathbf{m}\end{array}$ & $\begin{array}{l}\mathbf{E} \\
\mathbf{u} \\
\end{array}$ & $\begin{array}{l}\text { G } \\
\text { d }\end{array}$ & $\begin{array}{l}\text { D } \\
\mathbf{y}\end{array}$ & $\mathbf{E r}$ & $\mathbf{Y b}$ & Lu \\
\hline $\begin{array}{l}\text { Cerro Rio } \\
\text { Chubut }\end{array}$ & $\mathrm{CH} 8$ & $\begin{array}{l}\mathrm{n} . \\
\mathrm{m}\end{array}$ & $\begin{array}{l}\mathrm{n} . \\
\mathrm{m}\end{array}$ & - & - & $\begin{array}{c}0.70 \\
3873\end{array}$ & $\begin{array}{l}0.00 \\
0008\end{array}$ & $\begin{array}{l}\mathrm{n} . \\
\mathrm{m}\end{array}$ & $\begin{array}{l}\mathrm{n} . \\
\mathrm{m}\end{array}$ & - & - & $\begin{array}{c}0.512 \\
902\end{array}$ & $\begin{array}{l}0.00 \\
0016\end{array}$ & $\begin{array}{l}\mathrm{n} . \\
\mathrm{m}\end{array}$ & $\begin{array}{l}\mathrm{n} . \\
\mathrm{m}\end{array}$ & $\begin{array}{l}\mathrm{n} . \\
\mathrm{m}\end{array}$ & $\begin{array}{l}\mathrm{n} . \\
\mathrm{m}\end{array}$ & $\begin{array}{l}\mathrm{n} . \\
\mathrm{m}\end{array}$ & $\begin{array}{l}\mathrm{n} . \\
\mathrm{m}\end{array}$ & $\begin{array}{l}\mathrm{n} . \\
\mathrm{m}\end{array}$ & $\begin{array}{l}\mathrm{n} . \\
\mathrm{m} .\end{array}$ & $\begin{array}{l}\mathrm{n} . \\
\mathrm{m}\end{array}$ & $\begin{array}{l}\mathrm{n} . \\
\mathrm{m} .\end{array}$ \\
\hline
\end{tabular}

$\begin{array}{lllllllllllllllllllllll}12-12 & 49 & .1 & 16 & 3001 & 2736 & 0009 & 84 & 30 & 32 & 362 & 038 & 0018 & 89 & 67 & 30 & 84 & 71 & 85 & 67 & 7 & 6 & 2\end{array}$

$\begin{array}{llllllllllllllllllllllllllll}\mathrm{PM} & 0 . & 67 & 0.0 & 0.01 & 0.70 & 0.00 & 1 . & 3 . & 0.2 & 0.233 & 0.512 & 0.00 & 0 . & 3 . & 3 . & 1 . & 0 . & 2 . & 3 . & 2.1 & 2.0 & 0.3\end{array}$ $\begin{array}{llllllllllllllllllllllllll}12-13 & 45 & .9 & 15 & 8964 & 3417 & 0011 & 42 & 66 & 74 & 496 & 848 & 0020 & 90 & 06 & 66 & 42 & 57 & 16 & 15 & 8 & 2 & 0\end{array}$

$\begin{array}{lllllllllllllllllllllllllllll}\mathrm{PM} & 0 . & 68 & 0.0 & 0.02 & 0.70 & 0.00 & 1 . & 2 . & 0.3 & 0.207 & 0.512 & 0.00 & 0 . & 2 . & 2 . & 1 . & 0 . & 2 . & 3 . & 2.3 & 2.6 & 0.2\end{array}$ $\begin{array}{llllllllllllllllllllllllll}12-15 & 56 & .2 & 15 & 3748 & 3463 & 0008 & 01 & 94 & 41 & 552 & 89 & 0006 & 78 & 83 & 94 & 01 & 48 & 07 & 11 & 0 & 8 & 9\end{array}$ $\begin{array}{llllllllllllllllllllllllllllllll}\text { Cerro de los } & \text { PM } & 0 . & 99 & 0.0 & 0.01 & 0.70 & 0.00 & 2 . & 4 . & 0.2 & 0.291 & 0.512 & 0.00 & 0 . & 3 . & 4 . & 2 . & 0 . & 3 . & 3 . & 2.6 & 2.4 & 0.4\end{array}$ $\begin{array}{llllllllllllllllllllllllllll}\text { Chenques } & 12-17 & 60 & .1 & 10 & 7427 & 4077 & 0011 & 04 & 22 & 37 & 797 & 723 & 0022 & 90 & 38 & 22 & 04 & 87 & 30 & 95 & 9 & 9 & 1\end{array}$ $\begin{array}{lllllllllllllllllllllllllllll}\mathrm{PM} & 0 . & 73 & 0.0 & 0.02 & 0.70 & 0.00 & 1 . & 4 . & 0.2 & 0.244 & 0.513 & 0.00 & 1 . & 3 . & 4 . & 1 . & 0 . & 3 . & 3 . & 2.5 & 2.2 & 0.3\end{array}$ $\begin{array}{llllllllllllllllllllllllllll}12-19 & 67 & .9 & 14 & 6213 & 2704 & 0011 & 98 & 88 & 05 & 851 & 087 & 001^{\text {N }} & 26 & 78 & 88 & 98 & 76 & 29 & 98 & 4 & 3 & 3\end{array}$ $\begin{array}{llllllllllllllllllllllllll}\mathrm{PM} & 0 . & 88 & 0.0 & 0.03 & 0.70 & 0.00 & 0 . & 4 . & 0.2 & 0.141 & 0.512 & 0.00 & \text { ?. } & 7 . & 4 . & 0 . & 0 . & 0 . & 0 . & 0.3 & 0.5 & 0.1\end{array}$ $\begin{array}{lllllllllllllllllllllllllllll}12-26 & 93 & .5 & 11 & 0411 & 3696 & 0008 & 97 & 14 & 42 & 309 & 734 & 000 & 60 & 93 & 14 & 97 & 30 & 85 & 68 & 7 & 4 & 0\end{array}$ $\begin{array}{lllllllllllllllllllllllllllllll}\mathrm{PM} & 0 . & 84 & 0.0 & 0.01 & 0.70 & 0.00 & 1 . & 4 . & 0.2 & 0.203 & 0.512 & 0 & 0 & - & 7 . & 4 . & 1 . & 0 . & 1 . & 3 . & 2.2 & 1.6 & 0.2\end{array}$ \begin{tabular}{llllllllllllllllllllllllllllllllll}
$12-48$ & 54 & .9 & 12 & 8521 & 3988 & 0009 & 44 & 26 & 35 & 867 & 696 & 00.2 & -1 & 00 & 26 & 44 & 47 & 68 & 11 & 9 & 7 & 8 \\
\hline
\end{tabular}

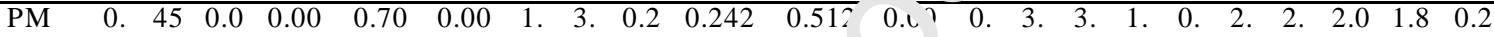
$\begin{array}{lllllllllllllllllllllllllll}24-22 & 10 & .7 & 22 & 6400 & 3432 & 0009 & 53 & 80 & 64 & 365 & 867 & 00 & 99 & 43 & 80 & 53 & 64 & 29 & 88 & 6 & 7 & 6\end{array}$ $\begin{array}{llllllllllllllllllllllllll}\text { Cerro Clark } & \text { PM } & 0 . & 18 & 0.0 & 0.00 & 0.70 & 0.00 & 2 . & 9 . & 0.1 & 0.136 & 0 . .^{-12} & \text { U.00 } & 9 . & 19 & 9 . & 2 . & 0 . & 2 . & 2 . & 1.5 & 1.5 & 0.2\end{array}$ $\begin{array}{lllllllllllllllllllllllll}24-27 & 17 & 6 & 05 & 2673 & 3236 & 0010 & 21 & 76 & 02 & 262 & 15 & 0010 & 28 & .1 & 76 & 21 & 79 & 38 & 74 & 0 & 0 & 2\end{array}$

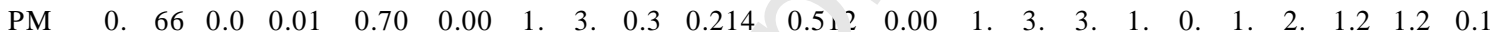

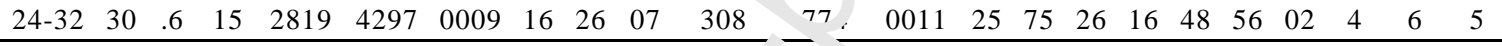

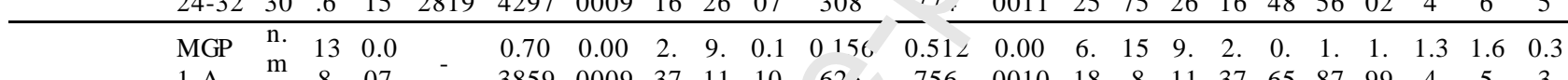

$\begin{array}{lllllllllllllllllllllllllllllll}\text { MGP } & \mathrm{n} . & 99 & 0.0 & & 0.70 & 0.00 & 1 . & 4 & 0 . & 0.168 & 0.512 & 0.00 & 3 . & 8 . & 4 . & 1 . & 0 . & 1 . & 1 . & 0.8 & 0.8 & 0.1\end{array}$ $\begin{array}{lccccccccccccccccccccccc}\text { Estancia Sol } & 2-\mathrm{A} & \mathrm{m} & .0 & 10 & - & 3706 & 0009 & 37 & 2 & 13 & 13 & 791 & 0022 & 74 & 37 & 92 & 37 & 44 & 41 & 55 & 2 & 0 & 5\end{array}$

$\begin{array}{lllllllllllllllllllllllllllllllll}\text { de Mayo } & \text { MGP } & \mathrm{n} . & 10 & 0.0 & & 0.70 & 0.00 & 1 . & 5 . & 0.1 & 0.175 & 0.512 & 0.00 & 3 . & 9 . & 5 . & 1 . & 0 . & 1 . & 2 . & 1.4 & 1.3 & 0.2\end{array}$ $\begin{array}{llllllllllllllllllllllllllllllll}2-\mathrm{B} & \mathrm{m} & 0 & 10 & - & 3743 & 0009 & 70 & 81 & 12 & 953 & 787 & 0012 & 81 & 13 & 81 & 70 & 59 & 95 & 26 & 0 & 9 & 1\end{array}$

$\begin{array}{lllllllllllllllllllllllllll}\text { MGP } & \mathrm{n} . & 12 & 0.0 & & 0.70 & 0.00 & & 0 & 1: & 0.0 & 0.160 & 0.512 & 0.00 & 5 . & 16 & 11 & 2 . & 0 . & 2 . & 2 . & 1.5 & 1.3 & 0.2\end{array}$ $\begin{array}{lllllllllllllllllllllllllllll}4-\mathrm{A} & \mathrm{m} & 5 & 08 & - & 3676 & 00 \mathrm{C}) & \text { ) } & .2 & 89 & 217 & 694 & 0032 & 36 & .6 & .2 & 97 & 94 & 80 & 99 & 7 & 8 & 1\end{array}$

$\begin{array}{llllllllllllllllllllllllllll}\mathrm{PM} & 0 . & 25 & 0.0 & 0.00 & 0.70 & 0.0 \mathrm{u} & 6 . & 23 & 0.0 & 0.174 & 0.512 & 0.00 & 8 . & 26 & 23 & 6 . & 2 . & 6 . & 4 . & 1.4 & \text { b.d } & 0.0 & \end{array}$ $\begin{array}{llllllllllllllllllllllll}23-1 & 22 & 8 & 04 & 2466 & 307^{7} 13 & 90 & .8 & 42 & 639 & 904 & 0007 & 23 & .7 & .8 & 90 & 19 & 53 & 45 & 5 & \text { b.d } & 7\end{array}$

$\begin{array}{lllllllllllllllllllllllllll}\mathrm{PM} & 0 . & 44 & 0.0 & 0.00 & 0 . \neg n & \iota .00 & 9 . & 36 & 0.0 & 0.160 & 0.512 & 0.00 & 29 & 57 & 36 & 9 . & 3 . & 8 . & 5 . & 1.6 & \text { b.d } & 0.1\end{array}$ $\begin{array}{cccccccccccccccccccccccccc}23-6 & 21 & 4 & 02 & 1391 & 3046 & 0009 & 59 & .0 & 28 & 854 & 947 & 0009 & .2 & .5 & .0 & 59 & 02 & 60 & 58 & 1 & \text { b.d } & 0\end{array}$

$\begin{array}{llllllllllllllllllllllllllllll}\mathrm{PM} & 0 . & 45 & 0.0 & 0 & 0 & 0 & 70 & 0.00 & 8 . & 37 & 0.0 & 0.132 & 0.512 & 0.00 & 21 & 56 & 37 & 8 . & 2 . & 6 . & 4 . & 1.9 & \text { b.d } & 0.2\end{array}$

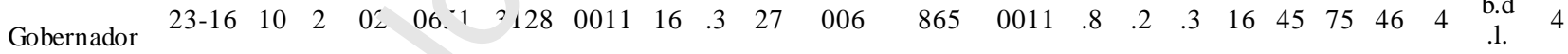
$\begin{array}{llllllllllllllllllllllllll}\text { Gregores } & \text { DUB } & \text { n. } & 19 & 0.0 & 0.70 & 0.00 & 2 . & 13 & 0.0 & 0.131 & 0.512 & 0.00 & 17 & 23 & 13 & 2 . & 1 . & 3 . & 2 . & 1.1 & 0.8 & \text { b.d }\end{array}$ $\begin{array}{cccccccccccccccccccccc}1 \mathrm{~g} \_1 & \mathrm{~m} & 4 & 05 & 3259 & 0007 & 90 & .3 & 75 & 510 & 872 & 0005 & .3 & .3 & .3 & 90 & 14 & 47 & 36 & 2 & 8 & \text { b.d } \\ \end{array}$

$\begin{array}{lllllllllllllllllllllllllllll}\text { DUB } & \text { n. } & 33 & 0.0 & & 0.70 & 0.00 & 5 . & 24 & 0.0 & 0.132 & 0.512 & 0.00 & 10 & 32 & 24 & 5 . & 1 . & 3 . & 2 . & 0.8 & 0.7 & \text { b. }\end{array}$

$\begin{array}{lllllllllllllllllllllllllll}1 \mathrm{~g} \_ & \mathrm{m} & \mathrm{m} & 3 & 03 & - & 3245 & 0009 & 29 & .1 & 41 & 169 & 866 & 0006 & .6 & .7 & .1 & 29 & 28 & 80 & 57 & 00 & 9 & \text { b.c }\end{array}$ $\begin{array}{lllllllllllllllllllllllll}\text { DUB } & \mathrm{n} . & 23 & 0.0 & & 0.70 & 0.00 & 7 . & 27 & 0.0 & 0.161 & 0.512 & 0.00 & 9 . & 34 & 27 & 7 . & 2 . & 6 . & 3 . & 1.6 & 0.9 & \text { b.d } \\ 2 \mathrm{~g} & \mathrm{~m} & 4 & 04 & - & 3345 & 0010 & 43 & .8 & 36 & 021 & 807 & 0005 & 75 & .0 & .8 & 43 & 10 & 27 & 90 & 3 & 8 & & \\ \end{array}$ $\begin{array}{llllllllllllllllllllllllll}\mathrm{CF} & \mathrm{n} & 21 & 0.0 & & 0.70 & 0.00 & 0 . & 2 . & 0.3 & 0.171 & 0.512 & 0.00 & 6 . & 9 . & 2 . & 0 . & 0 . & 0 . & 0 . & 0.3 & 0.4 & 0.0 \\ 6 \mathrm{~A} & \mathrm{~m} & .3 & 47 & & 3416 & 0007 & 77 & 71 & 69 & 525 & 922 & 0024 & 17 & 54 & 71 & 77 & 21 & 52 & 49 & 8 & 5 & 8\end{array}$ $\begin{array}{lllllllllllllllllll}3416 & 0007 & 77 & 71 & 69 & 525 & 922 & 0024 & 17 & 54 & 71 & 77 & 21 & 52 & 49 & 8 & 5 & 8\end{array}$

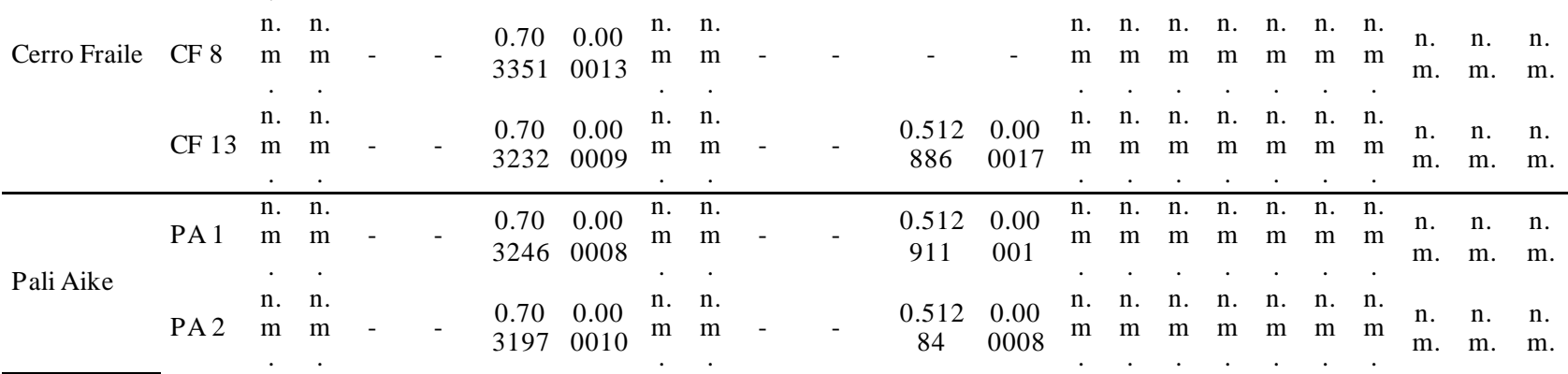




\begin{tabular}{|c|c|c|c|c|c|c|c|c|c|c|c|c|c|c|c|c|c|c|c|c|c|}
\hline PA 5 & $\begin{array}{c}\mathrm{n} . \\
\mathrm{m}\end{array}$ & $\begin{array}{l}\mathrm{n} . \\
\mathrm{m}\end{array}$ & - & - & $\begin{array}{l}0.70 \\
3338\end{array}$ & $\begin{array}{c}0.00 \\
0010\end{array}$ & $\begin{array}{l}\mathrm{n} . \\
\mathrm{m}\end{array}$ & $\begin{array}{c}\mathrm{n} . \\
\mathrm{m}\end{array}$ & - & - & $\begin{array}{c}0.512 \\
894\end{array}$ & $\begin{array}{c}0.00 \\
0009\end{array}$ & $\begin{array}{l}\mathrm{n} . \\
\mathrm{m}\end{array}$ & $\begin{array}{l}\mathrm{n} . \\
\mathrm{m}\end{array}$ & $\begin{array}{c}\mathrm{n} . \\
\mathrm{m}\end{array}$ & $\begin{array}{l}\mathrm{n} . \\
\mathrm{m}\end{array}$ & $\begin{array}{c}\mathrm{n} . \\
\mathrm{m}\end{array}$ & $\begin{array}{c}\mathrm{n} . \\
\mathrm{m}\end{array}$ & $\begin{array}{l}\mathrm{n} . \\
\mathrm{m}\end{array}$ & $\begin{array}{l}\mathrm{n} . \\
\mathrm{m} .\end{array}$ & $\begin{array}{l}\mathrm{n} . \\
\mathrm{m} .\end{array}$ \\
\hline PA 8 & $\begin{array}{l}\mathrm{n} . \\
\mathrm{m}\end{array}$ & $\begin{array}{l}\mathrm{n} . \\
\mathrm{m}\end{array}$ & - & - & $\begin{array}{l}0.70 \\
3216\end{array}$ & $\begin{array}{c}0.00 \\
0010\end{array}$ & $\begin{array}{l}\mathrm{n} . \\
\mathrm{m}\end{array}$ & $\begin{array}{l}\mathrm{n} . \\
\mathrm{m}\end{array}$ & - & - & $\begin{array}{c}0.512 \\
986\end{array}$ & $\begin{array}{c}0.00 \\
0009\end{array}$ & $\begin{array}{l}\mathrm{n} . \\
\mathrm{m}\end{array}$ & $\begin{array}{l}\mathrm{n} . \\
\mathrm{m}\end{array}$ & $\begin{array}{l}\mathrm{n} . \\
\mathrm{m}\end{array}$ & $\begin{array}{l}\mathrm{n} . \\
\mathrm{m}\end{array}$ & $\begin{array}{l}\mathrm{n} . \\
\mathrm{m}\end{array}$ & $\begin{array}{l}\mathrm{n} . \\
\mathrm{m}\end{array}$ & $\begin{array}{l}\mathrm{n} . \\
\mathrm{m}\end{array}$ & $\begin{array}{l}\mathrm{n} . \\
\mathrm{m} .\end{array}$ & $\begin{array}{l}\mathrm{n} . \\
\mathrm{m} .\end{array}$ \\
\hline $\begin{array}{l}\text { PA } \\
13\end{array}$ & $\begin{array}{l}\mathrm{n} . \\
\mathrm{m}\end{array}$ & $\begin{array}{c}\mathrm{n} . \\
\mathrm{m}\end{array}$ & - & - & $\begin{array}{c}0.70 \\
3464\end{array}$ & $\begin{array}{c}0.00 \\
0010\end{array}$ & $\begin{array}{l}\mathrm{n} . \\
\mathrm{m}\end{array}$ & $\begin{array}{l}\mathrm{n} . \\
\mathrm{m}\end{array}$ & - & - & $\begin{array}{c}0.512 \\
939\end{array}$ & $\begin{array}{c}0.00 \\
0012\end{array}$ & $\begin{array}{l}\mathrm{n} . \\
\mathrm{m}\end{array}$ & $\begin{array}{c}\mathrm{n} . \\
\mathrm{m}\end{array}$ & $\begin{array}{c}\mathrm{n} . \\
\mathrm{m}\end{array}$ & $\begin{array}{l}\mathrm{n} . \\
\mathrm{m}\end{array}$ & $\begin{array}{c}\mathrm{n} . \\
\mathrm{m}\end{array}$ & $\begin{array}{c}\mathrm{n} . \\
\mathrm{m}\end{array}$ & $\begin{array}{c}\mathrm{n} . \\
\mathrm{m}\end{array}$ & $\begin{array}{l}\mathrm{n} . \\
\mathrm{m} .\end{array}$ & $\begin{array}{l}\mathrm{n} . \\
\mathrm{m} .\end{array}$ \\
\hline
\end{tabular}

n.m. = not measured; b.d.l. = below

detection limit 
Table 2

Summary of the main geochemical features of the Northern, Central and Southern Patagonia mantle xenoliths. The latitude ( $\left.{ }^{\circ} \mathrm{S}\right)$, longitude $\left({ }^{\circ} \mathrm{W}\right)$, distance from trench $(\mathrm{km})$, age of the xenoliths-bearing host rock $(\mathrm{Ma})$ and xenoliths type are listed for each Patagonian locality, together with the identification number reported in Fig. 1. Additionally, Re-Os $\left(\mathrm{T}_{\mathrm{RD}}\right)$ ages, calculated partial melting degrees (F\%) experienced by orthopy roxene and clinopy roxene, and forsterite (Fo) content of olivine are also shown. Partial melting degrees and olivine Fo ranges are calculated/reported only for harzburgites and lherzolites. Sp $=$ spinel; Grt $=$ garnet; $\mathrm{Cpx}=$ clinopy roxene; $\mathrm{Opx}=$ orthopy roxene; $\mathrm{Ol}=$ olivine. $\mathrm{Hz}=$ harzburgite; $\mathrm{Lh}=$ lherzolite; $\mathrm{Du}=$ dunite; $\mathrm{Wh}=$ wehrlite; $\mathrm{Wb}=$ websterite; Opxite $=$ orthop y roxenite $; \mathrm{Cpxite}=$ clinopy roxenite. $*$ indicates values calculated only on spinel-bearing lherzolites and harzburgites.

\begin{tabular}{|c|c|c|c|c|c|c|c|c|c|c|c|}
\hline Locality (Number in Fig. 1) & $\begin{array}{l}\text { Latitude } \\
\quad\left({ }^{\circ} \mathbf{S}\right)\end{array}$ & $\begin{array}{l}\text { Longitude } \\
\left({ }^{\circ} \mathbf{W}\right)\end{array}$ & $\begin{array}{c}\text { Distance } \\
\text { from } \\
\text { trench } \\
(\mathbf{k m})\end{array}$ & $\begin{array}{l}\text { Type of } \\
\text { xenoliths }\end{array}$ & $\begin{array}{c}\text { Host } \\
\text { rock } \\
\text { age } \\
\text { (Ma) }\end{array}$ & $\begin{array}{c}\text { Xenoliths } \\
\text { T }_{\text {RD age }} \\
\text { (Ga) }\end{array}$ & $\begin{array}{c}\text { F(\%) } \\
\text { from } \\
\text { Opx } \\
\text { major } \\
\text { elements }\end{array}$ & $\begin{array}{c}\mathbf{F}(\%) \\
\text { from } \\
\text { Cpx } \\
\text { major } \\
\text { elements }\end{array}$ & $\begin{array}{c}\text { F(\%) } \\
\text { from } \\
\text { Cpx } \\
\text { trace } \\
\text { elements } \\
\end{array}$ & Fo $(\mathbf{O l})$ & Ref erences \\
\hline \multicolumn{12}{|c|}{ Northern Patagonia $\left(39 / 40^{\circ}-46^{\circ}\right)$} \\
\hline Laguna Fria (1) & $40^{\circ} 21^{\prime}$ & $68^{\circ} 38^{\prime}$ & 546 & $\mathrm{Sp}-\mathrm{Hz}$ & $1-5$ & - & - & - & - & 90.8 & $\begin{array}{l}\text { Bjerg et al. } \\
(2005)\end{array}$ \\
\hline Cerro Chenque (2) & $40^{\circ} 29^{\prime}$ & $68^{\circ} 44^{\prime}$ & 537 & $\begin{array}{c}\mathrm{Sp}-\mathrm{Hz} \\
\mathrm{Du}\end{array}$ & - & $0.5-1$ & $23-31$ & 18 & 14 & $91.0-91.9$ & $\begin{array}{l}\text { Mundl et } \\
\text { al. }(2016)\end{array}$ \\
\hline Puesto Diaz (3) & $40^{\circ} 30^{\prime}$ & $68^{\circ} 44^{\prime}$ & 537 & $\begin{array}{l}\text { Sp-Hz; } \\
\text { Du }\end{array}$ & - & $0.7-1$ & $2 \cdot 0$ & $18-21$ & $7-17$ & $90.8-91.8$ & $\begin{array}{l}\text { Mundl et } \\
\text { al. (2016) }\end{array}$ \\
\hline Estancia Alvarez (4) & $40^{\circ} 46^{\prime}$ & $68^{\circ} 45^{\prime}$ & 531 & $\begin{array}{l}\text { Sp-Lh; } \\
\text { Sp-Hz }\end{array}$ & - & - & $\therefore \quad 20$ & - & - & $90.0-90.5$ & $\begin{array}{l}\text { Rivalenti et } \\
\text { al. (2004) }\end{array}$ \\
\hline Cerro Aznares (5) & $40^{\circ} 48^{\prime}$ & $68^{\circ} 41^{\prime}$ & 540 & $\mathrm{~Wb}$ & $\begin{array}{c}20- \\
29\end{array}$ & - & & - & - & $89.5-91.0$ & $\begin{array}{l}\text { Dantas } \\
(2007)\end{array}$ \\
\hline Comallo (6) & $40^{\circ} 55^{\prime}$ & $69^{\circ} 52^{\prime}$ & 437 & $\mathrm{Sp}-\mathrm{Hz}$ & $1-2$ & $0.6-13$ & $1-27$ & $17-20$ & $7-13$ & $91.1-91.9$ & $\begin{array}{l}\text { Mundl et } \\
\text { al. (2016) }\end{array}$ \\
\hline Cerro Mojon (7) & $41^{\circ} 06^{\prime}$ & $70^{\circ} 13^{\prime}$ & 415 & $\begin{array}{l}\text { Sp-Lh; } \\
\text { Sp-Hz; } \\
\text { Du }\end{array}$ & - & & - & $18-20$ & $6-15$ & $91.0-91.5$ & $\begin{array}{l}\text { Conceicao } \\
\text { et al. } \\
(2005) \text {; } \\
\text { Rivalenti et } \\
\text { al. (2004) }\end{array}$ \\
\hline Prahuaniyeu $(\mathbf{8})$ & $41^{\circ} 20^{\prime}$ & $67^{\circ} 54^{\prime}$ & 613 & $\begin{array}{c}\text { Sp-Lh; } \\
\text { Sp-Hz; } \\
\text { Sp-Wb; } \\
\text { Sp+G i- } \\
\text { I h; - } \\
\text { h }\end{array}$ & $\begin{array}{l}0- \\
-0\end{array}$ & $0.6-1.7$ & $10-23^{*}$ & $7-25^{*}$ & $6-20 *$ & $89.2-91.7$ & $\begin{array}{l}\text { Bjerg et al. } \\
\text { (2009); } \\
\text { Dantas } \\
\text { (2007); } \\
\text { Mundl et } \\
\text { al. (2016) }\end{array}$ \\
\hline Traful (9) & $41^{\circ} 38^{\prime}$ & $69^{\circ} 18^{\prime}$ & 497 & $\mathrm{p}-\mathrm{Hz}$ & $\begin{array}{l}23- \\
25\end{array}$ & - & - & - & - & 91.6 & $\begin{array}{l}\text { Bjerg et al. } \\
(2005)\end{array}$ \\
\hline Cerro Rio Chubut (10) & $43^{\circ} 38^{\prime}$ & $68^{\circ} 58^{\prime}$ & 53. & $\begin{array}{c}\mathrm{S}_{\mathrm{H}} \mathrm{h} \\
\mathrm{Sp}-\mathrm{Hz} \\
\mathrm{Sp}-\mathrm{Wb} \\
\mathrm{Wb}\end{array}$ & $\begin{array}{c}49- \\
52\end{array}$ & - & $11-30$ & $6-17$ & $1-10$ & $89.5-92.0$ & $\begin{array}{l}\text { Dantas } \\
\text { (2007); } \\
\text { This work }\end{array}$ \\
\hline Paso de los Indios (11) & $43^{\circ} 48^{\prime}$ & $68^{\circ} 55^{\prime}$ & 5,6 & $\begin{array}{l}\text { Sp-Lh; } \\
\text { Sp-Hz }\end{array}$ & $\begin{array}{c}23- \\
34\end{array}$ & - & - & $17-21$ & $13-14$ & $90.0-91.5$ & $\begin{array}{l}\text { Rivalenti et } \\
\text { al. (2004) }\end{array}$ \\
\hline Cerro de los Chenques (12) & $44^{\circ} 52^{\prime}$ & $\because 7004$ & 456 & $\begin{array}{c}\text { Sp-Lh; } \\
\text { Sp-Hz; } \\
\text { Du; Sp- } \\
\text { Wb }\end{array}$ & $\begin{array}{l}20- \\
25\end{array}$ & - & $14-27$ & $10-22$ & $3-15$ & $88.8-91.4$ & $\begin{array}{l}\text { Dantas } \\
\text { (2007); } \\
\text { Dantas et } \\
\text { al. (2009); } \\
\text { Rivalenti et } \\
\text { al. (2004, } \\
\text { 2007); This } \\
\text { work }\end{array}$ \\
\hline Coyhaique (13) & 4. ' $35^{\prime}$ & $2^{\circ} 08^{\prime}$ & 300 & Sp-Lh & $\begin{array}{r}57- \\
61 \\
\end{array}$ & $1.31-1.7$ & $27-30$ & - & - & $91.2-91.5$ & $\begin{array}{l}\text { Schilling et } \\
\text { al. }(2017)\end{array}$ \\
\hline \multicolumn{12}{|l|}{ Central Patagonia $\left(46^{\circ}-49^{\circ}\right)$} \\
\hline Chile Chico (14) & $46^{\circ} 34$ & $71^{\circ} 46^{\prime}$ & 306 & Sp-Lh & $\begin{array}{l}39- \\
42\end{array}$ & $0.81-0.88$ & $23-26$ & 10 & - & $90.0-90.3$ & $\begin{array}{l}\text { Schilling et } \\
\text { al. (2017) } \\
\text { Dantas }\end{array}$ \\
\hline Cerro Clark (15) & $46^{\circ} 43^{\prime}$ & $69^{\circ} 29^{\prime}$ & 476 & $\begin{array}{l}\text { Sp-Lh; } \\
\text { Sp-Wb; } \\
\text { Sp- } \\
\text { Cpxite; } \\
\text { Cpxite }\end{array}$ & $\begin{array}{c}11- \\
12\end{array}$ & $0.78-0.82$ & $12-17$ & $10-17$ & $2-8$ & $89.0-90.7$ & $\begin{array}{l}\text { (2007); } \\
\text { Dantas et } \\
\text { al. (2009); } \\
\text { Schilling et } \\
\text { al. (2017); } \\
\text { This work }\end{array}$ \\
\hline Estancia Sol de Mayo (16) & $46^{\circ} 49^{\prime}$ & $71^{\circ} 25^{\prime}$ & 326 & $\begin{array}{l}\text { Sp-Lh; } \\
\text { Sp-Hz; } \\
\text { Du; Wh }\end{array}$ & $2-7$ & - & $19-30$ & $17-21$ & - & $88.1-91.8$ & $\begin{array}{l}\text { Melchiorre } \\
\text { et al. } \\
\text { (2015); } \\
\text { This work }\end{array}$ \\
\hline Don Camilo (17) & $46^{\circ} 59^{\prime}$ & $68^{\circ} 32^{\prime}$ & 552 & $\begin{array}{l}\text { Sp-Lh; } \\
\text { Sp-Hz }\end{array}$ & $0-5$ & 0.9 & - & $12-17$ & $3-7$ & - & $\begin{array}{l}\text { Mundl et } \\
\text { al. (2015) }\end{array}$ \\
\hline Cerro Cuadrado (18) & $48^{\circ} 07^{\prime}$ & $70^{\circ} 08^{\prime}$ & 474 & $\begin{array}{l}\text { Sp-Lh; } \\
\text { Sp-Hz }\end{array}$ & - & - & $13-24$ & $12-16$ & $1-8$ & $89.6-91.3$ & $\begin{array}{l}\text { Rivalenti et } \\
\text { al. (2004) }\end{array}$ \\
\hline Auvernia (19) & $48^{\circ} 27^{\prime}$ & $68^{\circ} 10^{\prime}$ & 625 & $\begin{array}{l}\text { Sp-Lh; } \\
\text { Sp-Hz }\end{array}$ & $0-1$ & $1.59-2.13$ & $22-27$ & $13-15$ & - & $91.1-91.7$ & $\begin{array}{l}\text { Schilling et } \\
\text { al. (2017) }\end{array}$ \\
\hline Gobernador Gregores (20) & $48^{\circ} 34^{\prime}$ & $70^{\circ} 10^{\prime}$ & 487 & $\begin{array}{c}\text { Sp-Lh; } \\
\text { Sp-Hz; } \\
\text { Wh; Wb }\end{array}$ & $3-4$ & $0.5-1.86$ & $8-31$ & $3-22$ & $3-17$ & $87.5-92.1$ & $\begin{array}{l}\text { Aliani et al. } \\
\text { (2009); } \\
\text { Conceicao } \\
\text { et al. } \\
\text { (2005); } \\
\text { Dantas } \\
\text { (2007); } \\
\text { Gorring }\end{array}$ \\
\hline
\end{tabular}




\begin{tabular}{|c|c|c|c|c|c|c|c|c|c|c|c|}
\hline Cerro Redondo (21) & $48^{\circ} 59^{\prime}$ & $70^{\circ} 10^{\prime}$ & 495 & $\begin{array}{l}\text { Sp-Lh; } \\
\text { Sp-Hz }\end{array}$ & - & - & $15-24$ & $8-22$ & - & 90.3-91.5 & $\begin{array}{l}\text { and Kay } \\
\text { (2000); } \\
\text { Laurora et } \\
\text { al. (2001); } \\
\text { Mundl et } \\
\text { al. (2015); } \\
\text { Rivalenti et } \\
\text { al. (2004); } \\
\text { This work } \\
\text { Conceicao } \\
\text { et al. } \\
\text { (2005); } \\
\text { Schilling et } \\
\text { al. (2005) }\end{array}$ \\
\hline \multicolumn{12}{|c|}{ Southern Patagonia $\left(49^{\circ}-54^{\circ}\right)$} \\
\hline Tres Lagos (22) & $49^{\circ} 11^{\prime}$ & $71^{\circ} 20^{\prime}$ & 412 & $\begin{array}{l}\text { Sp-Lh; } \\
\text { Sp-Hz; } \\
\text { Du }\end{array}$ & $4-7$ & $0.6-2.0$ & $10-30$ & $9-19$ & $1-14$ & 88.9-91.3 & $\begin{array}{l}\text { Mundl et } \\
\text { al. (2015); } \\
\text { Ntaflos et } \\
\text { al. (2007); } \\
\text { Rivalenti et } \\
\text { al. (2004) }\end{array}$ \\
\hline Cerro Fraile (23) & $50^{\circ} 33^{\prime}$ & $72^{\circ} 38^{\prime}$ & 284 & $\begin{array}{l}\text { Sp-Lh; } \\
\text { Sp-Hz; } \\
\text { Du; } \\
\text { Cpxite; } \\
\text { Opxite } \\
\text { Sp-Lh; }\end{array}$ & $1-2$ & $0.81-2.04$ & $12 \ldots$ & $12-23$ & $4-21$ & $88.0-91.0$ & $\begin{array}{l}\text { Faccini et } \\
\text { al. (2013); } \\
\text { Rivalenti et } \\
\text { al. (2004); } \\
\text { This work }\end{array}$ \\
\hline Las Cumbres (24) & $50^{\circ} 42^{\prime}$ & $72^{\circ} 20^{\prime}$ & 304 & $\begin{array}{l}\text { Sp-Hz; } \\
\text { Du }\end{array}$ & - & & $1,-25$ & $17-18$ & $5-12$ & $88.4-89.8$ & $\begin{array}{l}\text { Rivalenti et } \\
\text { al. (2004) }\end{array}$ \\
\hline Pali Aike (25) & $52^{\circ} 01^{\prime}$ & $70^{\circ} 09^{\prime}$ & 406 & $\begin{array}{l}\text { Sp-Lh; } \\
\text { Sp-Hz; } \\
\text { Sp+Grt- } \\
\text { Lh; Grt- } \\
\text { Lh;Grt- } \\
\quad \text { Hz }\end{array}$ & $0-3$ & 2.5 & $12-18^{*}$ & $7-25^{*}$ & $2-24 *$ & 87.9-90.7 & $\begin{array}{l}\text { Dantas } \\
\text { (2007); } \\
\text { Mundl et } \\
\text { al. (2015); } \\
\text { This work }\end{array}$ \\
\hline
\end{tabular}




\section{Highlights}

Southern Patagonia mantle experienced lower partial melting degrees in older times

Refertilization and metasomatic processes occurred in Patagonia lithospheric mantle

Enrichment processes were intimately related to the uprising back-arc plateau lavas

Pyroxenites record infiltration of tholeiitic and alkaline melts within lis mantle 


\section{Declaration of interests}

$\bigotimes$ The authors declare that they have no known competing financial interests or personal relationships that could have appeared to influence the work reported in this paper. 


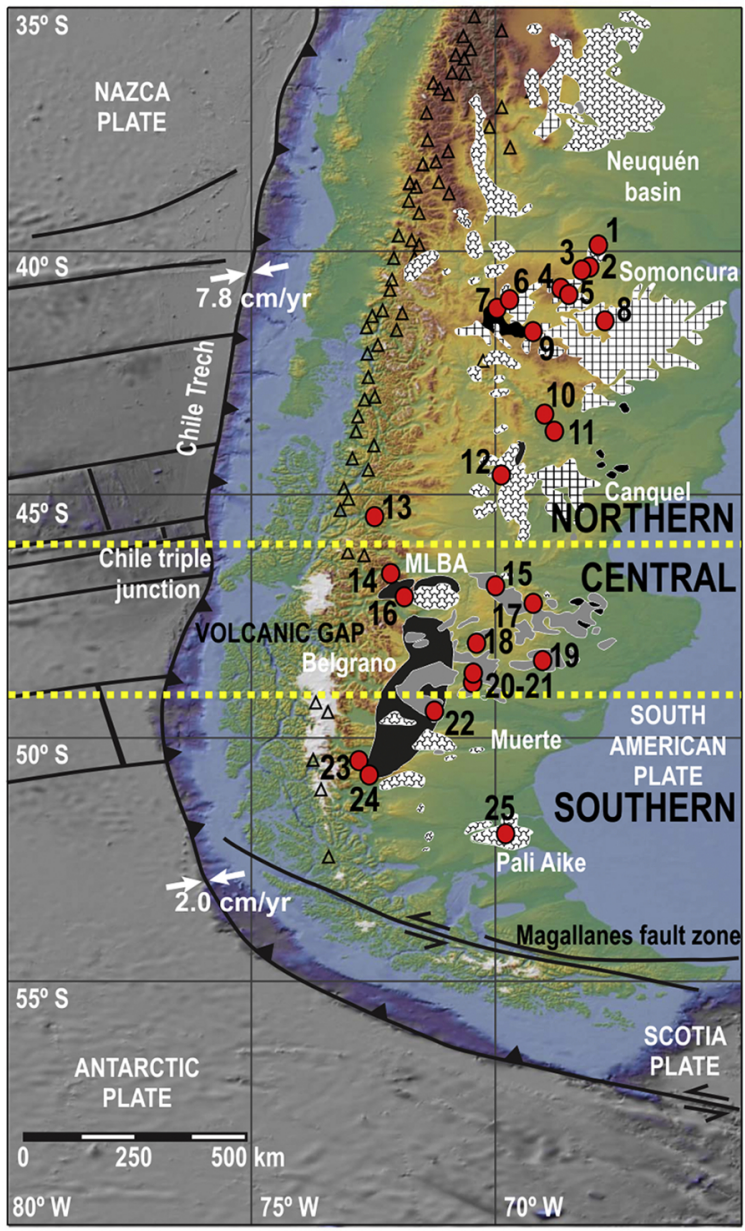

Eocene 蹬㺼Holocene to Pliocene 曲Early Miocene to Oligocene $\triangle$ Volcanoes $\square$ Pliocene to late Miocene $\bigcirc$ Mantle xenoliths localities 


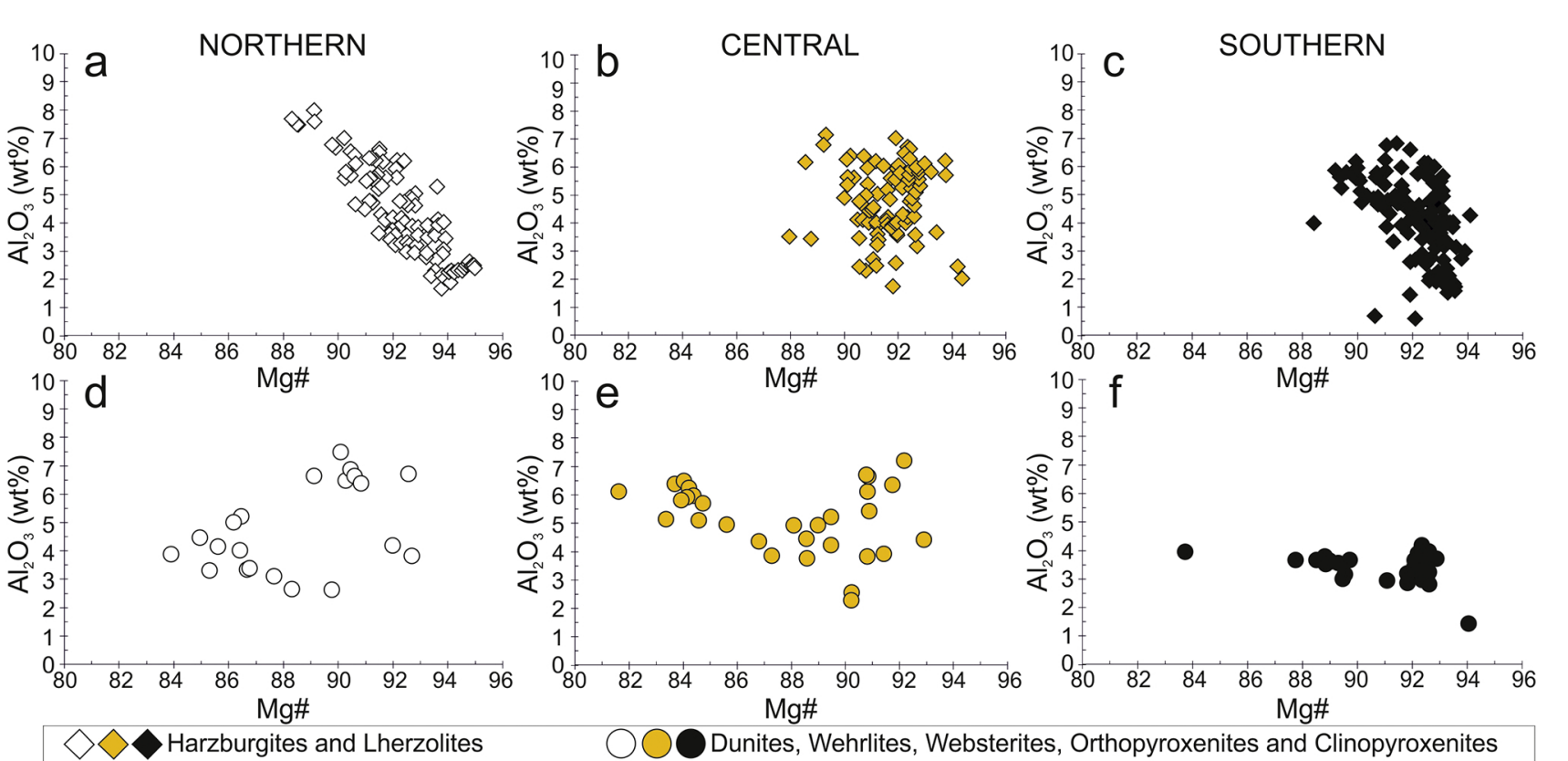

Figure 2 


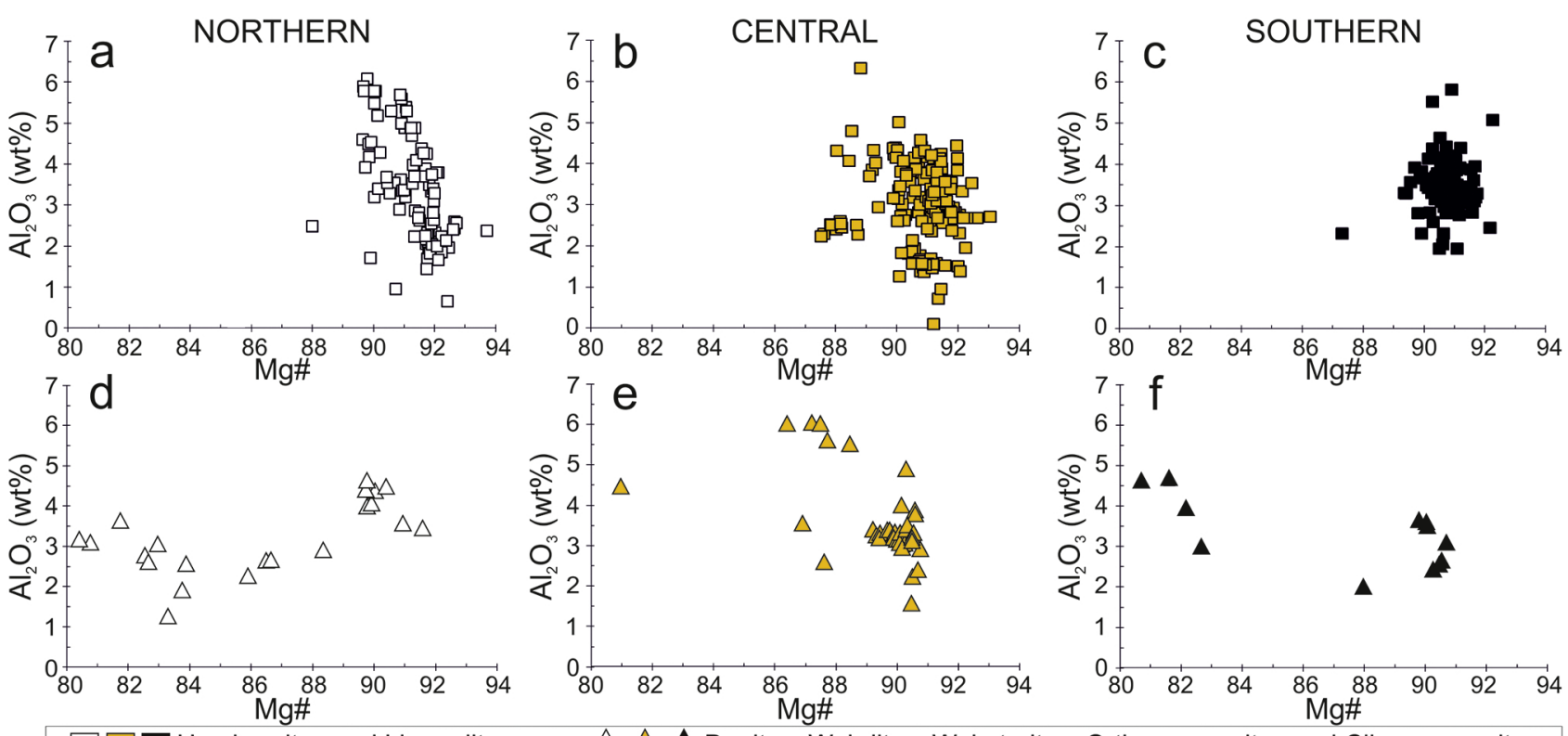




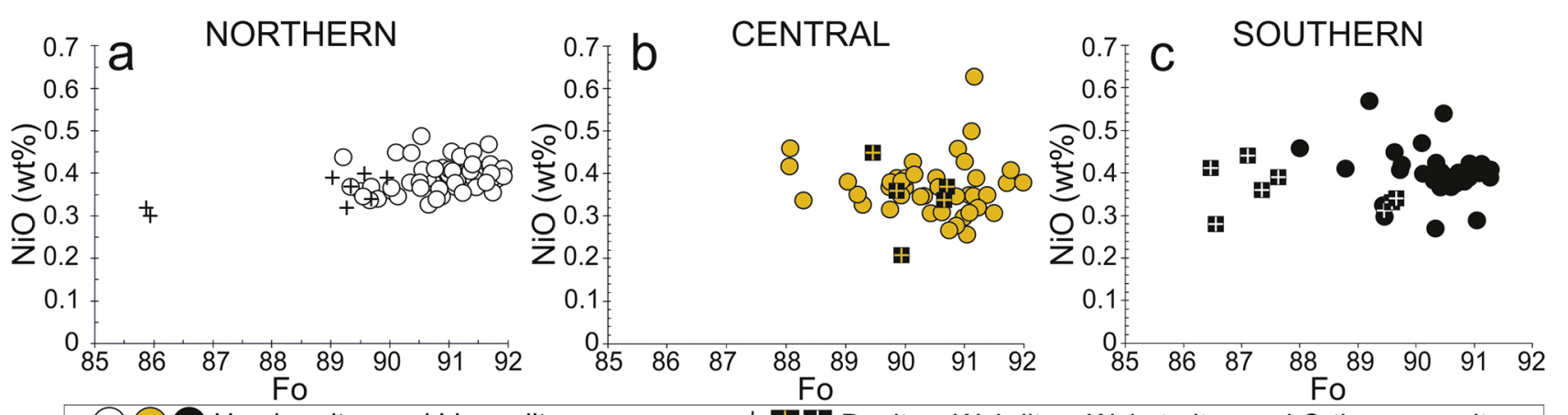




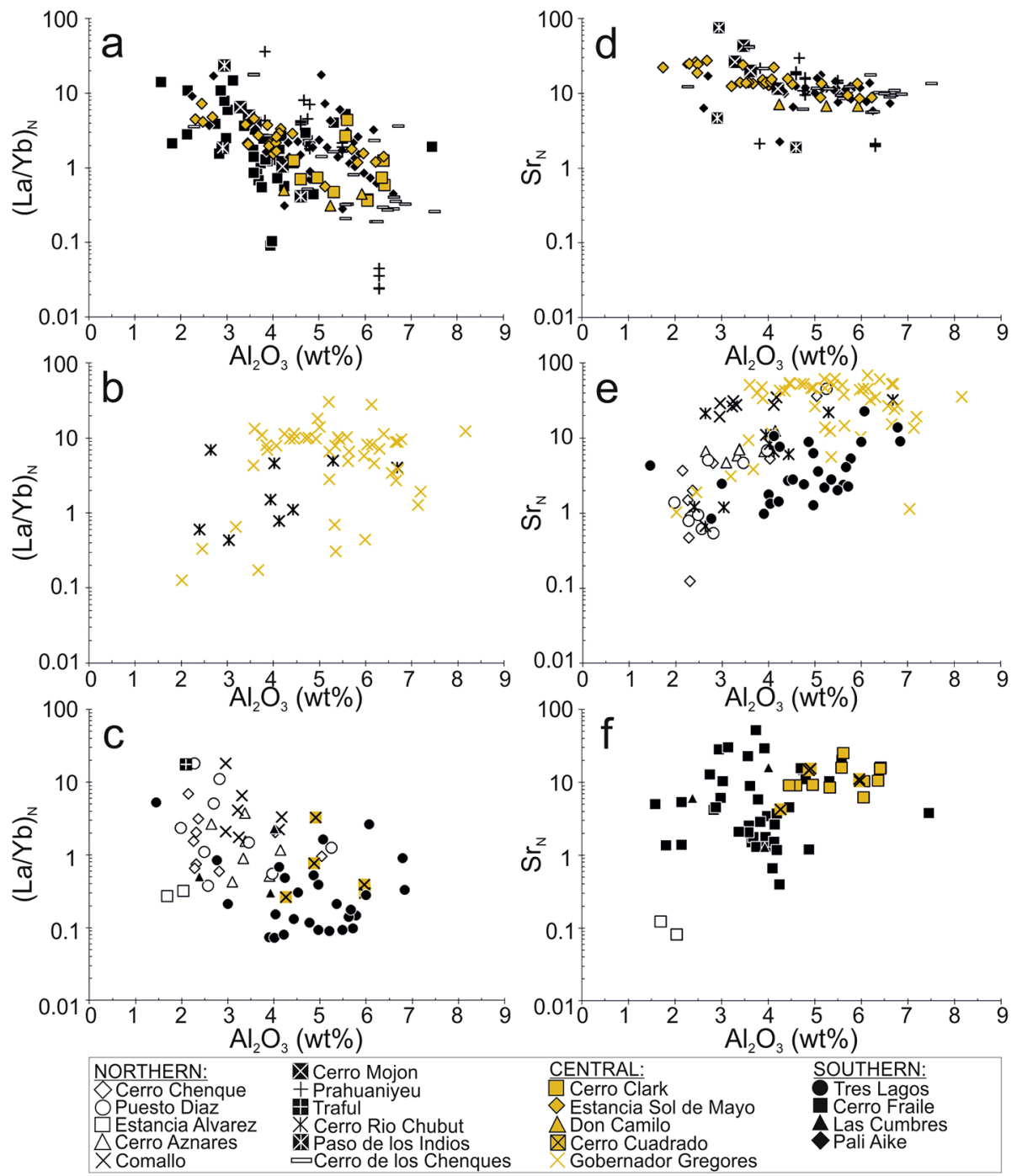




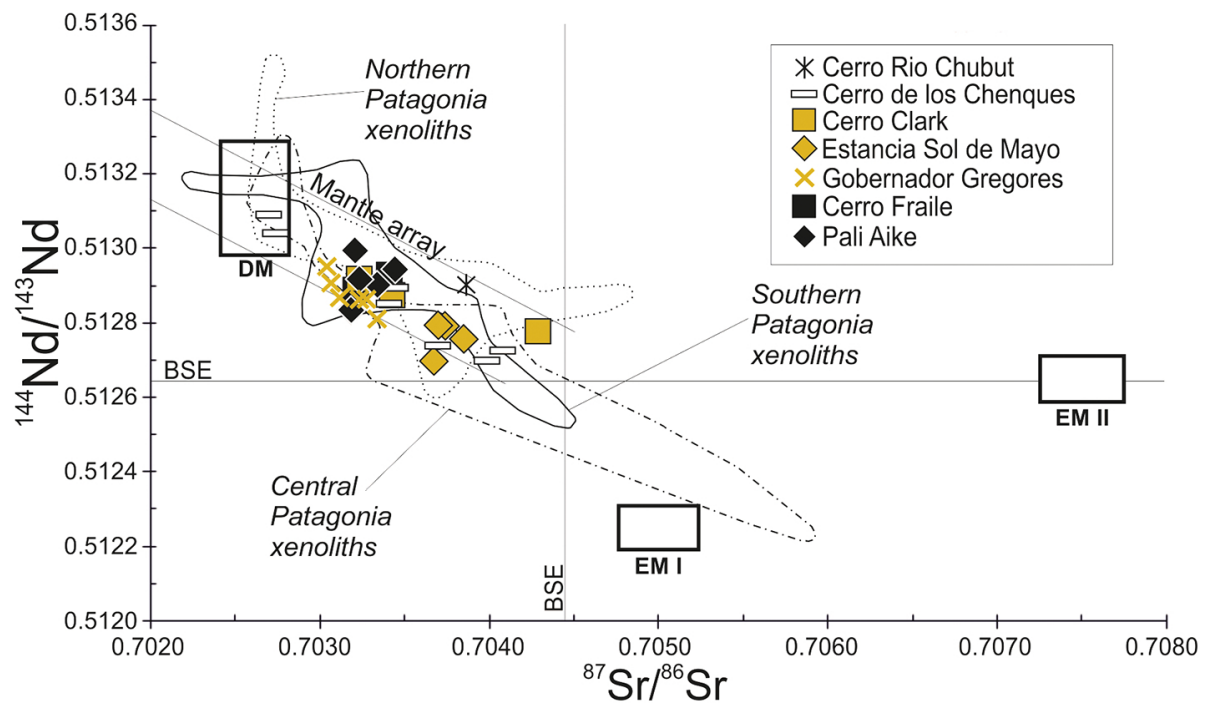

Figure 6 


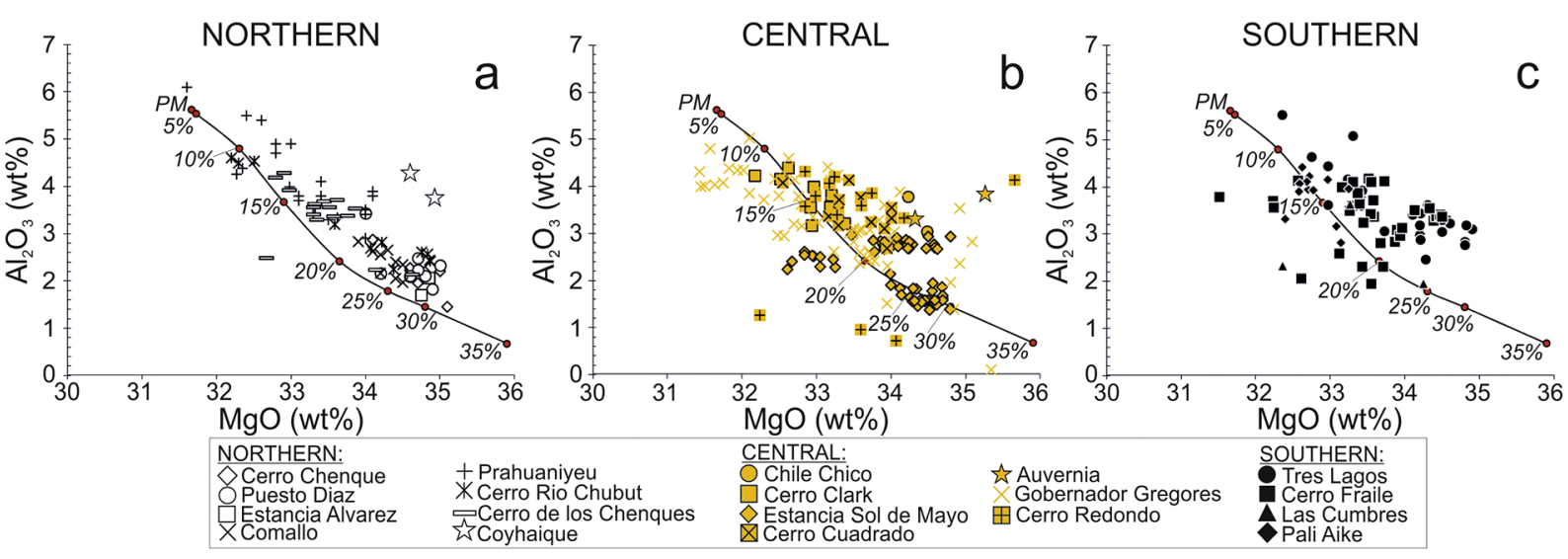

Figure 7 


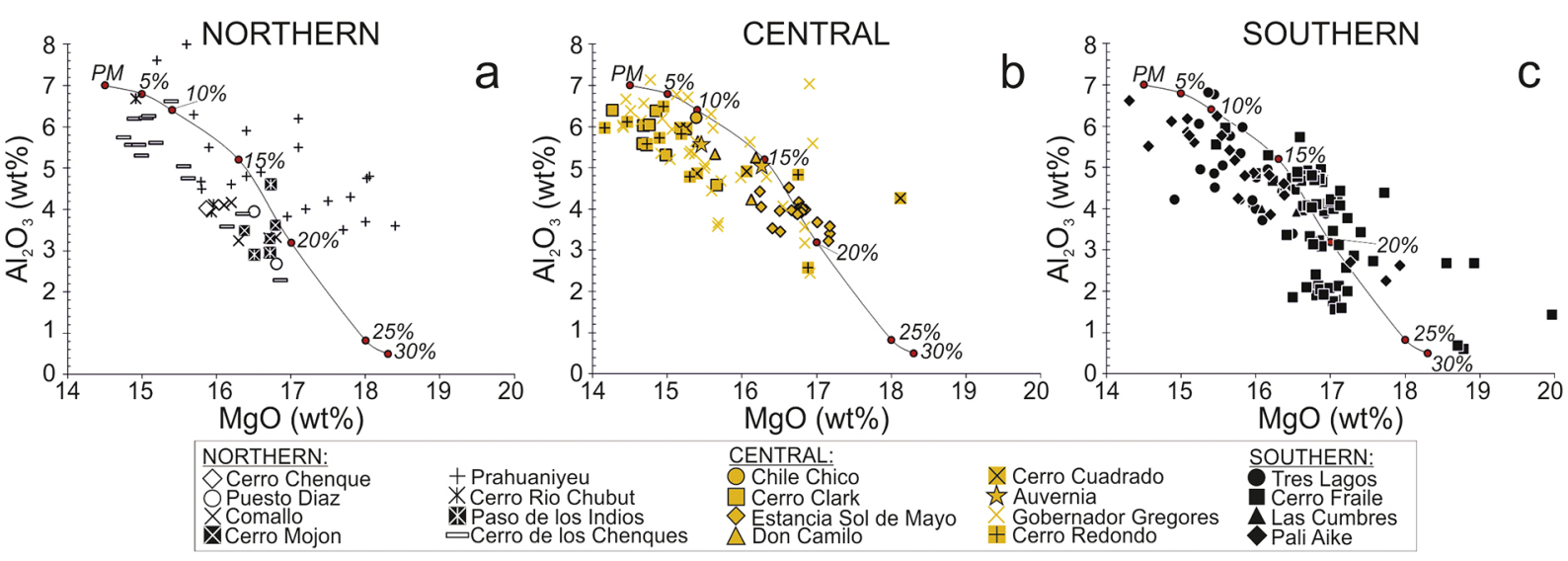

Figure 8 


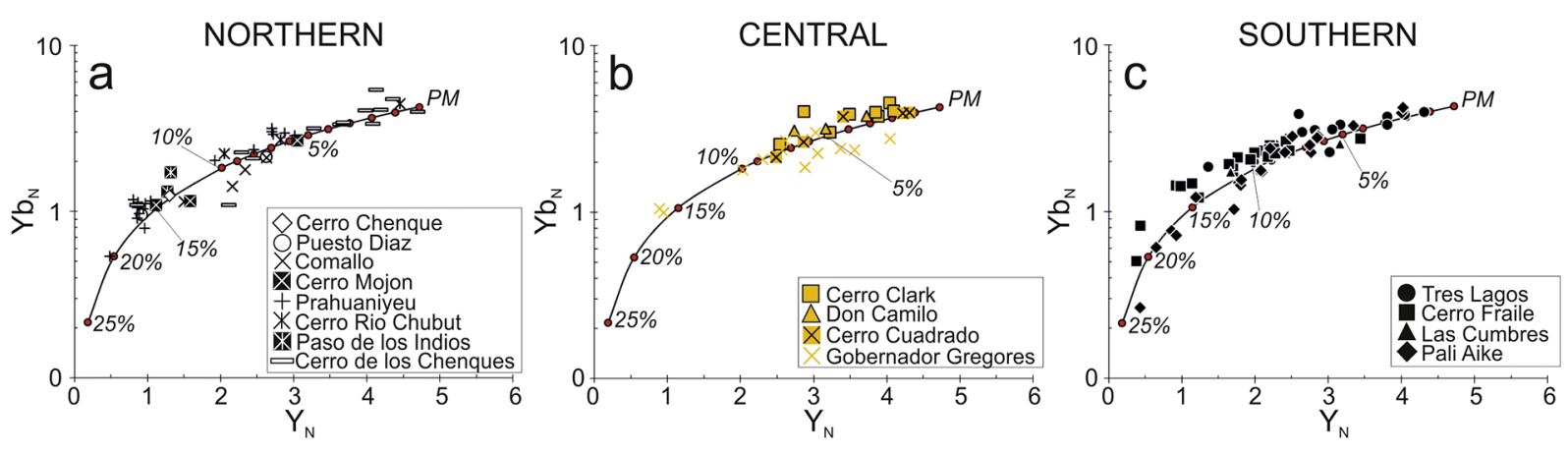

Figure 9 

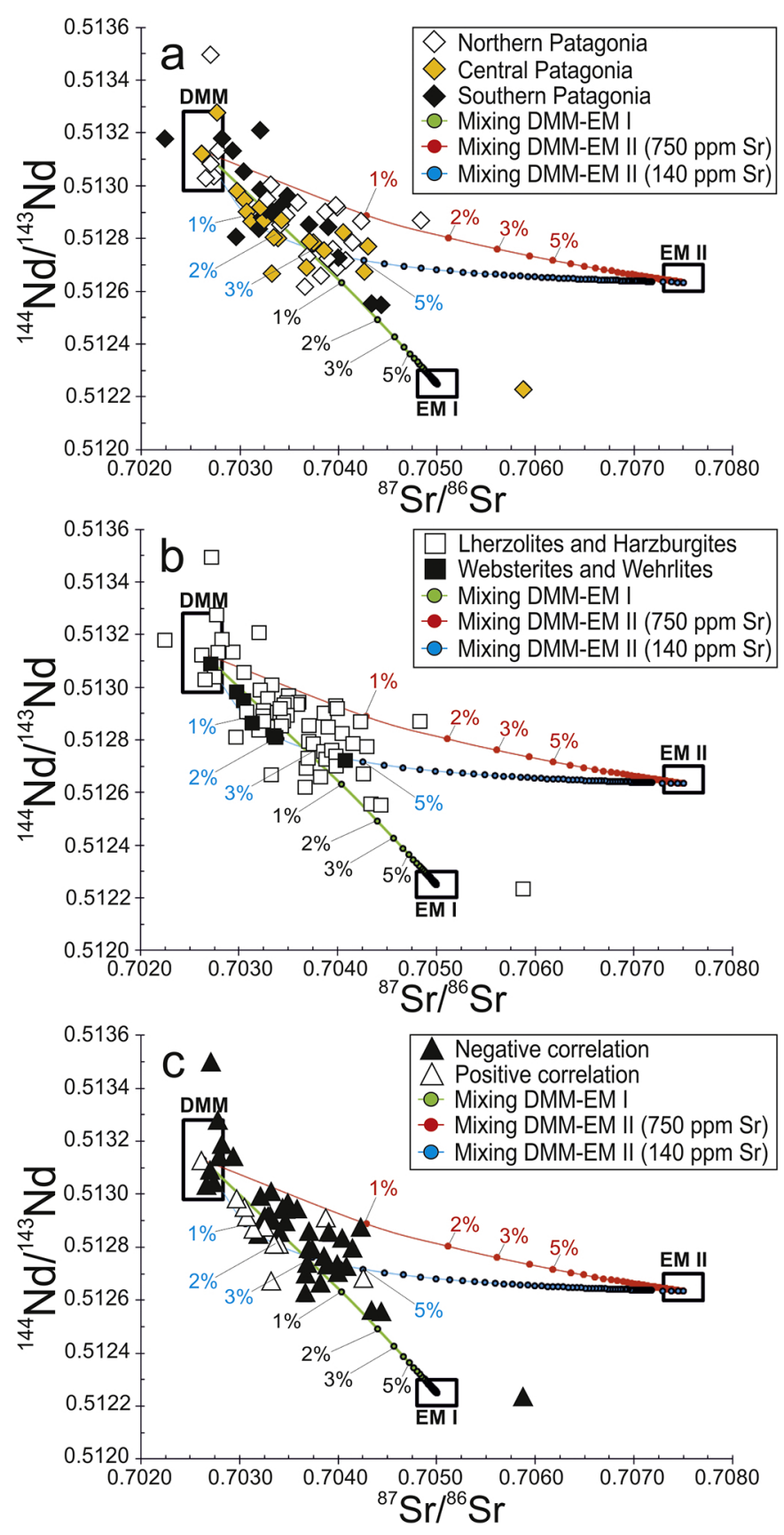

Figure 10 


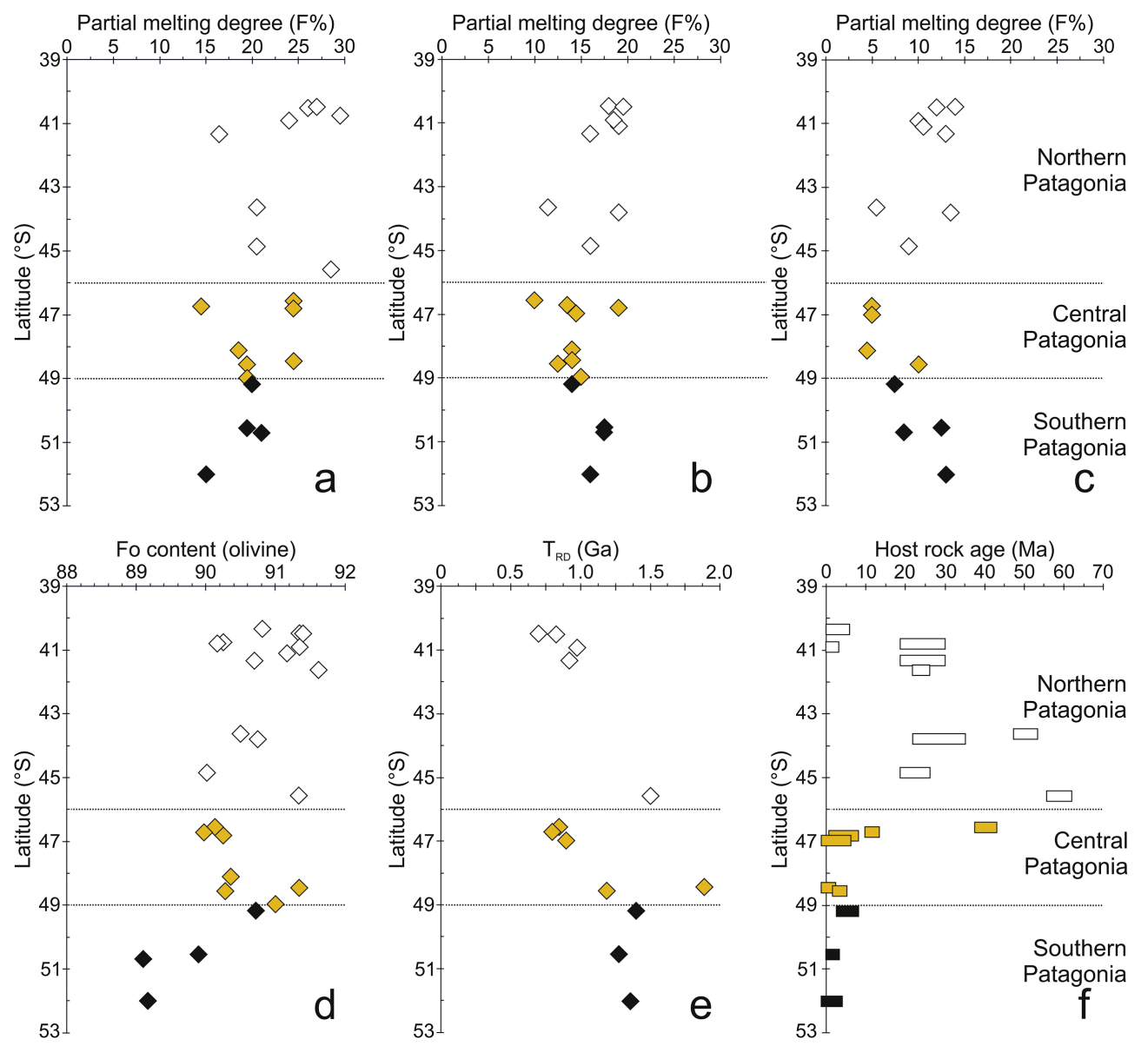

Figure 11 


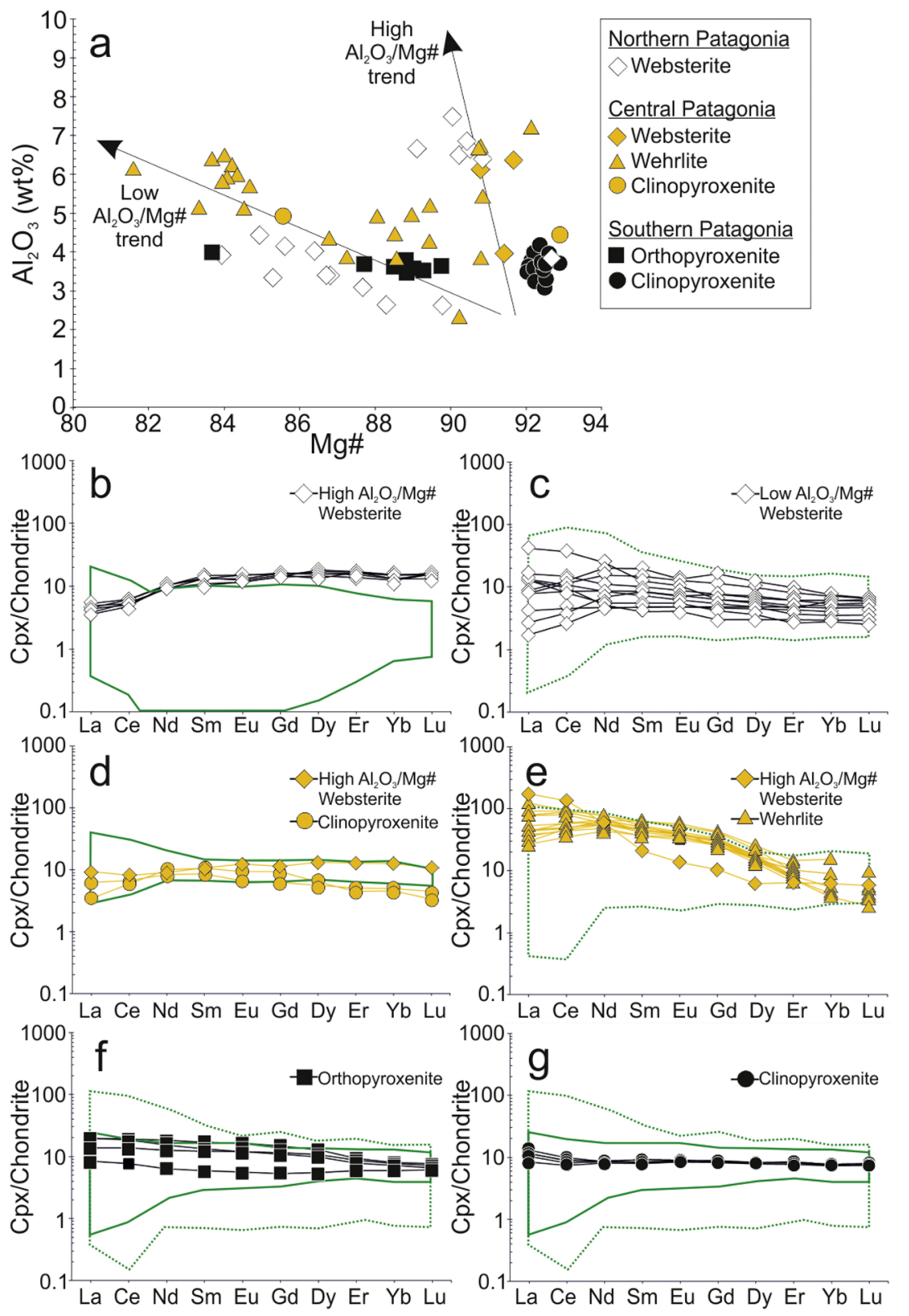

